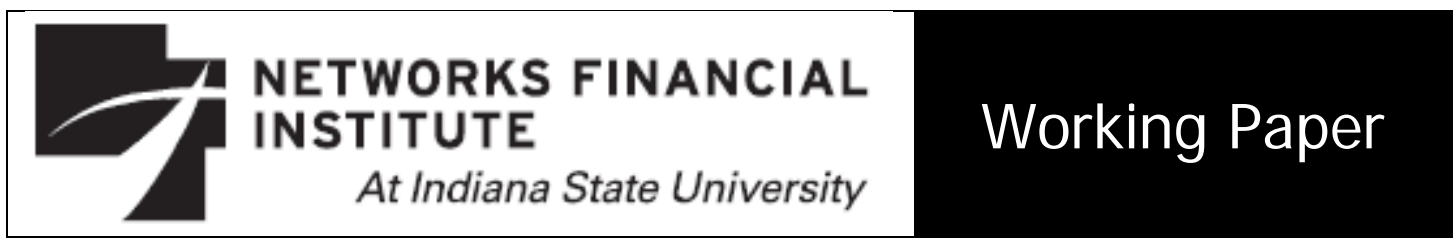

2016-WP-01

August 2016

\title{
Friends in the Right Places: The Effect of Political Connections on Corporate Merger Activity
}

\section{Stephen P. Ferris, Reza Houston and David Javakhadze}

Abstract: This study examines how the appointment of former politicians and regulators to boards of directors or management teams influences corporate acquisition activity and performance. We find that bidders with political connections are more likely to acquire targets and avoid regulatory delay or denial. The merger premium paid increases with political connectedness. The announcement period returns show that investors recognize that bids by politically connected acquirers are more likely to create firm value. Connected bidders make more bids and bid on larger targets. Connected acquirers also enjoy superior post-merger financial and operating performance.

About the Authors: Stephen P. Ferris is Interim Dean, J. H. Rogers Chair of Money, Credit and Banking, and Director of the Financial Research Institute. He was awarded an M.B.A. and Ph.D. from the University of Pittsburgh. His research interests include capital markets: the regulation of capital markets, corporate governance, bankruptcy and legal analysis of corporate activity. Reza Houston is an Assistant Professor of Finance and the Research Director of the Networks Financial Institute. Reza holds a Ph.D. in finance from the University of Missouri, and an MBA from Indiana State University. He has served as a journal referee, presented numerous papers, and acted as a discussant at international conferences. He currently maintains research interests in the role of the political economy, credit risk, and mergers and acquisitions. David Javakhadze is an Assistant Professor of Finance at Florida Atlantic University. David holds a Ph.D. in business administration from University of Missouri - Columbia where he also holds a MBA.

Keywords: Political Connections; Mergers; Acquisitions; Antitrust Law.

J EL classification: G34, G38, K21

The views expressed are those of the individual authors and do not necessarily reflect official positions of Networks Financial Institute. Please address questions regarding content to Reza Houston at reza.houston@indstate.edu. Any errors or omissions are the responsibility of the authors.

NFI working papers and other publications are available on NFI's website (www.networksfinancialinstitute.org). Click "Research" and then "Publications/Papers." 


\title{
Friends in the Right Places: The Effect of Political Connections on Corporate Merger Activity
}

by

\author{
Stephen P. Ferris \\ -Trulaske College of Business \\ University of Missouri \\ 403 Cornell Hall \\ Columbia, MO 65211 USA \\ (573) 882-3089 \\ ferriss@missouri.edu \\ Reza Houston ${ }^{1}$ \\ Scott College of Business \\ Indiana State University \\ 30 N. $7^{\text {th }}$ St. Rm 103 \\ Terre Haute, IN 47803 USA \\ (812) 241-2395 \\ reza.houston@indstate.edu \\ and \\ David Javakhadze \\ College of Business \\ Florida Atlantic University \\ 777 Glades Road \\ Boca Raton, FL 33431 \\ (561) 297-2914 \\ djavakhadze@fau.edu
}

8 August 2016

We are grateful for the helpful comments and suggestions by John S. Howe, Dan French, Raynolde Pereira, Michael Gibbs, Ryan Flugum, David Maslar, and the participants of the seminar at the University of Missouri. We also thank the Center for Responsive Politics for providing the data on PAC contributions.

\footnotetext{
${ }^{1}$ Corresponding author
} 


\title{
Friends in the Right Places: The Effect of Political Connections on Corporate Merger Activity
}

\begin{abstract}
This study examines how the appointment of former politicians and regulators to boards of directors or management teams influences corporate acquisition activity and performance. We find that bidders with political connections are more likely to acquire targets and avoid regulatory delay or denial. The merger premium paid increases with political connectedness. The announcement period returns show that investors recognize that bids by politically connected acquirers are more likely to create firm value. Connected bidders make more bids and bid on larger targets. Connected acquirers also enjoy superior post-merger financial and operating performance.
\end{abstract}

JEL Classification: G34, G38, K21

Keywords: Political Connections; Mergers; Acquisitions; Antitrust Law 


\section{Friends in the Right Places: The Effect of Political Connections on Corporate Merger Activity}

\section{Introduction}

In the United States there is a substantial interaction between the parties to a merger and the reviewing regulatory agencies. Publicly traded firms that have finalized merger agreements must clear each potential deal with several governmental organizations, including the Federal Trade Commission, the Antitrust Division of the Department of Justice, and the various states' Attorneys General. These agencies determine whether the merger harms competition or creates significant barriers to entry. If they do, the reviewing agencies can then take regulatory action that will delay or prevent the deal from occurring.

To navigate this regulatory review process and achieve more favorable results, firms sometime hire former politicians or regulators to serve on their boards of directors or management team. Former politicians or regulators possess unique knowledge of the regulations and practices of the various regulatory agencies that are charged with merger review. Their knowledge can help the firm avoid costly litigation or regulatory complications (Brezis, Paroush, and Weiss, 2003). These individuals often maintain relationships with current regulators or politicians which can be helpful in gaining access for direct lobbying. In the extreme, such relationships might influence the outcome of an agency's merger review.

The goal of this study is to determine whether the appointment of such individuals to the board of directors or management team benefit bidders during the merger process. To answer this question we examine whether politically connected bidders are more likely to acquire targets while simultaneously avoiding regulatory action. Then we compare the number and size of bids 
made by politically connected and non-connected firms. Next we examine whether acquirer political connections have an effect on the takeover premium. In addition, we investigate whether the market recognizes the benefits associated with bidder political connections through an analysis of the merger announcement period returns. Finally, we test whether the long-term post-merger performance of politically connected acquirers exceeds that of non-connected bidders.

Our empirical findings show that political connections matter. We discover that politically connected bidders are more likely to acquire targets than non-politically connected bidders. The targets of connected firms are also larger than those of non-connected acquirers. This result persists even after we control for prior acquisition activity. These firms are also less likely to face regulatory action from either the Federal Tarde Commission (FTC) or the Department of Justice's Antitrust Division than non-connected bidders. Further, because politically connected acquirers are less likely to suffer adverse regulatory actions these firms have greater flexibility in selecting profitable targets than nonconnected bidders. Therefore political connectedness increases potential gains from takeovers while simultaneously causing acquirers to pay more for their targets.

Investors also appear to recognize greater value in the targets of politically connected acquirers. We examine the announcement period returns of both connected and non-connected bidders. We find that connected acquirers have less negative abnormal returns around the bid announcements than non-connected acquirers. This result supports our hypothesis that bidders with strong political connections are able to acquire more valuable targets than bidders without a political network. When we examine the investor response during the merger review period, we find investors respond more positively to events that resolve uncertainty for non-connected 
acquirers. This result suggests investors are more certain of the outcome of a regulatory action taken against connected bidders.

Finally, we determine that connected firms enjoy superior post-merger financial and accounting performance. Consistent with the premise that connected acquirers employ their knowledge and networks to pursue valuable acquisitions, we find these firms deliver higher buyand-hold abnormal return over the five years following the acquisition than non-connected acquirers. We further document that the industry-adjusted return on assets, estimated following the Wang and Xie (2009) procedure, is also higher for connected acquirers.

The work that examines the effect of political connections on merger activity and performance in the United States is very limited. Croci, Pantzalis, and Petmezas (2016) focus their analysis on merger targets. They find that when these potential targets make political contributions or are involved in lobbying, they are less likely to be acquired and their takeover process is lengthier. Our study complements Croci et al. (2016) since our analysis centers on the acquirer's political connections. We find that these connections also affect the merger process. This study also aligns with the work of Faccio (2006) and Goldman, Rocholl, and So (2009) who show value creation with the appointment of politically connected individuals to corporate positions.

\section{Regulation of the Merger Process in the United States}

In the United States, the two primary agencies overseeing merger activity are the Federal Trade Commission (FTC) and the Antitrust Division of the Department of Justice. Under the Hart-Scott-Rodino Antitrust Improvement Act of 1976, merging parties are required to provide 
pre-merger notification to these agencies and the Assistant Attorney General. ${ }^{2}$ The decision to prevent a proposed merger is based on criteria such as the combined market share of the proposed merged entity, the availability of substitute products, and the ability of competitors to procure component products post-merger. If the overseeing agency determines the deal does not violate any of these criteria, it will either waive the merger waiting period or allow the waiting period to expire. After the waiting period expires, the firms can merge.

If a regulatory agency has concerns about the effect of a proposed deal on market competition or consumer welfare, it can make a second request for information. From 1997 to 2013, between $2.1 \%$ and $4.5 \%$ of all transactions reviewed annually by the FTC received a second request. ${ }^{3}$ The Department of Justice requested additional information from approximately 3\% of all mergers over the years, 1998 to $2005 .^{4}$ The majority of merger parties who face second requests typically experience regulatory actions that delay or ultimately deny the merger.

When a regulatory agency determines a proposed merger limits competition, prevents new firms from entering the market, or allows the merged firm to raise prices, the regulatory agency has various options. ${ }^{5}$ In recent years, approximately half of the Department of Justice challenges against transactions have been filed in a U.S. district court. The vast majority of these complaints are resolved through settlements. If the Department of Justice does not file a

\footnotetext{
${ }^{2}$ Merging parties which do not meet the thresholds listed by the Federal Trade Commission are not required to complete premerger notification. An updated list of the thresholds can be found here: http://www.ftc.gov/system/files/attachments/current-2014-thresholds/140123clayton7afrn.pdf One or more State Attorneys General can file injunctions to block a proposed merger. State Attorneys General are often involved in joint investigations with the Federal Trade Commission or the Department of Justice.

${ }^{3}$ The FTC maintains records on the annual percentage of transactions which face second requests for information here: https://www.ftc.gov/policy/reports/policy-reports/annual-competition-reports

${ }^{4}$ https://www.ftc.gov/sites/default/files/attachments/merger-review/mergerreviewprocess.pdf

${ }^{5}$ Since 1996, the Federal Trade Commission has filed at least 319 cases against proposed acquisitions. The Department of Justice has filed several hundred cases over the same period. A large percentage of injunctions are filed against publicly traded U.S. firms.
} 
complaint in court, the merger parties abandon the transaction, restructure the transaction, or agree to a consent order to change their conduct. Challenges by the Federal Trade Commission most often result in accepted consent orders which prevent the merger parties from undertaking specific actions. In recent years, less than $30 \%$ of the challenges by the FTC resulted in transactions being abandoned or restructured. ${ }^{6}$

\section{The Benefits of Political Connections During the Merger Process}

The appointment of former regulators or politicians provides two major advantages to firms during the merger review process. First, these individuals might have insider information concerning the merger process or the practices of the reviewing agencies. The knowledge possessed by former government officials could help management structure a merger that avoids a second request or other adverse regulatory action. Their knowledge might also prove valuable should the regulatory agencies decide to alter or block the transaction. Second, former government officials might offer a firm the ability to network or lobby with current regulators or politicians who can influence the regulatory outcome. The following sections elaborate on the benefits associated with the hiring of politically connected directors.

\subsection{Information Advantage of Former Government Officials}

Former members of regulatory agencies that oversee the merger process might have nonpublic information concerning the specific factors that are most likely to trigger a second request. Appointing former regulators or politicians to their boards/management team can help firms construct a merger proposal that is more likely to pass regulatory scrutiny.

\footnotetext{
${ }^{6}$ See the FTC reports on actions for 2012 and 2013: https://www.ftc.gov/system/files/documents/reports/36threport-fy2013/140521hsrreport.pdf and https://www.ftc.gov/sites/default/files/documents/reports annual/35threport-fy2012/130430hsrreport_0.pdf
} 
Knowledge of the regulatory process can prove valuable even if a regulatory agency makes a second request for information or challenges the transaction. Both the Department of Justice and FTC negotiate with representatives of the merger parties to narrow the demand for documents during the second request (Egge and Cruise, 2014). Firms that employ former regulators or politicians often enjoy a negotiating advantage in this process. During negotiations, an acquirer that possesses greater knowledge of agency practices due to strategic director recruitment can better select tactics to produce a successful outcome.

\subsection{Networking Benefits of Former Government Officials}

Current government officials might not always have the incentive to act in the public's best interest. Merging firms can provide future employment opportunities, campaign contributions, and other benefits to regulators or politicians. In exchange, regulators or politicians offer support for the merger, even if it is not advantageous to the public.

The prospect of future industry employment can cause regulators to alter their behavior in favor of prospective employers when enforcing regulations. For instance, Cornaggia, Cornaggia, and Xia (2016) find that credit analysts provide more favorable ratings to the firms they eventually work for after leaving their job as a ratings analyst. Thus the possibility of future employment might influence how regulators or politicians behave during a regulatory proceeding.

Campaign contributions also impact the voting behavior of politicians (Salamon and Siegfried, 1977; Monardi and Glantz, 1998; Stratmann, 2002; Hillman, Keim, and Schuler, 2004). Stratmann (2002) finds the roll call voting of politicians regarding financial services regulations is positively correlated with changes in campaign contributions. Monardi and Glantz (1998) examine the impact that campaign contributions of tobacco companies have on the voting 
behavior of politicians. Their findings indicate that campaign contributions lead politicians to vote more favorably on laws affecting the tobacco industry. In aggregate, the prior literature shows that campaign contributions and other lobbying activity lead politicians to more favorably review the industries they are assigned to regulate.

One of the most common and effective ways firms convince current government officials to collaborate is by hiring former officials with whom current government officials continue to maintain relationships (Goldman et al., 2009; Boubakri, et al., 2012). Regulators and politicians are likely to be influenced by individuals whom they are connected. A strong relationship with current FTC Commissioners, division staff and Section Chiefs of the Department of Justice, or Deputy Assistant Attorneys General can influence the regulatory outcome. Perhaps even more important than the network with regulators is that with politicians.

Firms that network with current politicians receive support along two channels. First are letters of support that politicians can write to endorse the proposed transaction. ${ }^{7}$ Letters of support are provided during the comment period and suggest to regulatory agencies that the public is amenable to the transaction. Second, the House and Senate Judiciary Committees can hold hearings on proposed mergers. Open hearings can influence public support for a proposed merger, which then can be conveyed to the regulatory agencies during the waiting/comment period of the review process.

\section{Hypotheses Regarding Mergers and Corporate-Political Relations}

The decision to take regulatory action against a proposed merger is made by a commission that reviews the products each firm produces, its patents, its major suppliers and

\footnotetext{
${ }^{7}$ During Comcast's acquisition of NBC Universal, approximately 113 congressmen, senators, and state representatives signed letters of support for the transaction: https://www.fcc.gov/transaction/comcast-nbcu-cgo
} 
buyers, and perhaps most importantly, the current and projected post-merger market

concentration. Consequently, the knowledge and connections that former government officials can provide to acquirers is highly valuable in this process.

Because of the close interaction between regulators and the merger parties during the review process, acquirers can often gauge whether regulatory authorities are likely to oppose an acquisition. Recent cases like Comcast's abandonment of its bid for Time Warner Cable and Applied Materials’ abandonment of its bid for Tokyo Electron suggest that acquirers will abandon bids when regulators signal that opposition. In merger deals which involve firms operating in different industries, however, it is less likely that antitrust issues would arise that require political connections to resolve. Political connections are more likely to be needed when the target is in the same industry as the acquirer. This is because regulators are more likely to perceive anti-competitive market concentration issues in such mergers. Consequently, we hypothesize:

Hypothesis 1a: The non-diversifying bids by politically connected acquirers are more likely to close than those of non-politically connected acquirers.

Regulatory authorities can decide to approve a merger, deny it, or delay it through the demand for more information. With political connections, acquirers are more capable of designing a deal that passes regulatory scrutiny. Thus, connected firms can expect their deals to be approved more quickly than those of non-connected acquirers. Therefore, we hypothesize:

Hypothesis $1 b$ : The non-diversifying bids by politically connected acquirers are less likely to face regulatory delay or denial than those of non-politically connected acquirers.

Prior research such as Varaiya (1987) and Crawford and Lechner (1996) proposes that the price offered by a bidding firm should reflect both the underlying value of the target firm and all potential gains a bidder can make from the takeover. Because political networks help 
acquirers to close the deal with an increased potential for synergy due to increased market power. We offer the following hypothesis:

Hypothesis 2: Acquirer political connectedness is positively associated with the takeover premium for non-diversifying mergers.

When news of a bid is announced, the response of investors should reflect the added value provided by the target. Prior studies find share prices of acquirers fall surrounding the announcement of a bid on a public target (e.g., Roll, 1986; Bradley, Desai, and Kim, 1988; Mulherin and Boone, 2000; Fuller, Netter, and Stegemoller, 2002). But if politically connected acquirers are better able to pursue value enhancing targets due to relaxed regulatory oversight, then the market response to their merger announcement should be more positive. Consequently, we hypothesize:

Hypothesis 2: The cumulative abnormal returns around a merger bid announcements are higher for politically connected bidders.

If politically connected acquirers are less likely to suffer adverse averse regulatory action by the Federal Trade Commission or the Department of Justice, then these firms have greater latitude in selecting acquisition targets. That is, their overall merger activity is less likely to be scrutinized. Therefore, we expect firms which are politically connected to be more active in the merger market. Consequently, we hypothesize:

Hypothesis 3: Politically connected acquirers make more bids and acquisitions than nonconnected acquirers.

The likelihood of regulatory denial or delay should be the greatest for the bids of large merger targets because of their potential to intensify market concentration. Acquirers that are politically connected, however, might be better able to acquire larger targets due to their greater ability to navigate the review process and to influence regulators. Therefore, we hypothesize that: 
Hypothesis 4: Politically connected acquirers pursue larger targets than non-connected acquirers.

It might be that politically connected acquirers enjoy a more relaxed regulatory oversight of their merger activity. This can allow them to pursue competition limiting, market concentrating, or supply constraining acquisitions more efficiently. It is these types of acquisitions that are most likely to generate economic rents for the acquirers. Therefore we argue that:

Hypothesis 5: The long-term post-merger operating (accounting) performance of politically connected acquirers engaged in non-diversifying merger deals is superior to the long-term postmerger operating performance of non-politically connected acquirers.

\section{Sample Construction and the Measurement of Political Connectivity}

\subsection{Sample Construction and Data Measurement}

We use the CRSP and Compustat databases to obtain data on returns and financial statements. Our sample period extends from 1997 to 2013. We begin our sample in 1997 because that year the Securities and Exchange Commission's EDGAR database began recording a majority of the proxy statements issued by firms. To construct our sample we employ five filters:

1) Both the acquirer and target must be U.S. public companies

2) Target and acquirer must be included on the CRSP and Compustat databases

2) The deal must be listed on the SDC database

3) The deal must be larger than $\$ 1$ million

4) The acquirer owned less than $50 \%$ of the outstanding shares of the target six months prior to the bid announcement and seeks to acquire more than $90 \%$ after the deal.

5) The relative size of the deal value to bidder size is at least $1 \%$. 


\subsection{Identifying Regulatory Action}

The Federal Trade Commission and the Antitrust Division of the Department of Justice provide information on enforcement actions around mergers. ${ }^{8}$ We hand-collect data from both of these websites. The FTC or Department of Justice reports regulatory action against seventyfour of the deals in our sample. Approximately $80 \%$ of the actions result in a divestment of assets by one or both parties. Approximately $16.2 \%$ of cases result in a prohibition on the merger parties from engaging in certain activities. In $63 \%$ of these deals the acquirers have political connections. As a result of action from regulators, $8.7 \%$ of politically connected acquirers were unable to complete the acquisition, while the corresponding value is $12 \%$ for the politically non-connected acquirers.

\subsection{Measuring Political Connections}

Using data from individual firm proxy statements, we construct three indicator variables to measure political connectivity. All measures are binary variables, equaling one if the bidder is politically connected and zero otherwise. Our first measure, POL1, indicates whether the bidder has a former politician or industry regulator on its board or management team. Our second measure of political connectivity ( $P O L 2)$, indicates whether a bidder employs a former politician, regulator, general, or admiral. In our last measure of political connectivity, POL3, we

\footnotetext{
${ }^{8}$ This is the FTC database for merger cases filed against merging firms: http://www.ftc.gov/bc/caselist/merger/index.shtml

The DOJ database which records the mergers which the DOJ has filed briefs against: http://www.justice.gov/atr/cases/index.html\#page=page-1
} 
define a bidder as connected if the firm has a former politician, regulator, general/admiral, or non-counsel lawyer on the board or management team and zero otherwise. We elect to include lawyers in this last measure of political connections because of their numerous interactions with Department of Justice officials.

\section{Descriptive and Comparative Sample Characteristics}

\subsection{Univariate Sample Statistics}

In Panel A of Table 1, we examine the frequency and type of merger bids made by publicly traded U.S. firms. We separate our sample into politically connected and non-connected firms based on their connections at the time of their first bid. We observe that politically connected bidders make more bids and public acquisitions than non-connected acquirers. The 1,074 unique public bidders in our sample make a total of 1,752 public bids (Panel B).

When we separate the sample based on our most restrictive measure of political connections (POL1), we find that connected acquirers make an average of 1.272 public merger bids per year. Non-connected bidders make an average of only 1.161 bids for public targets. The difference between these values is statistically significant. When we use the more inclusive POL2 and POL3 measures of political connection, the results are qualitatively identical.

Politically connected firms also undertake more acquisitions than non-connected firms. We define acquisitions as offers provided by the SDC database where the Date Effective is available and the acquirer owns $100 \%$ of the equity of the target at the end of the transaction. Connected acquirers make an average of 1.270 acquisitions of public targets per year while nonconnected acquirers undertake an average of 1.149 public acquisitions during the sample period. This difference is also statistically significant between the subsamples. 
Next we examine whether the type of merger differs between connected and nonconnected firms. We define horizontal mergers as those in which the acquirer and target share the same primary 4-digit SIC code. We find that, in general, connected acquirers make more horizontal bids and acquisitions than non-connected acquirers. To identify whether a merger is vertical, we follow Fan and Goyal (2006) and Acemoglu, Johnson, and Mitton (2009) and use the industry commodity flow information from the Use 2002 Table of Benchmark Input-Output Accounts for the US Economy compiled by the BEA. ${ }^{9}$ As in Acemoglu et al. (2009), we calculate a vertical relatedness coefficient which represents the value of inputs required to produce one dollar's worth of outputs. We identify the top $5 \%$ of industry pairs as vertically integrated. We fail to find any difference between connected and non-connected firms regarding vertical bids and acquisitions.

In Panel B of Table 1, we test for time-series patterns in the bidding behavior of connected and non-connected firms. We find that overall number of merger bids of both sets of firms decreases over our sample period. This might reflect a long-term cooling off in the M\&A market for public firms (Harford, 2005; Duchin and Schmidt, 2013). We observe, however, no time-series difference between connected and non-connected acquirers.

\subsection{Industry Patterns}

We examie the number of bids made by connected and non-connected acquirers across industries in Table 2. For this table we assign firms to industries using the classification scheme of Fama and French 12 industries to allow for simplicity of presentation. We find that the

\footnotetext{
${ }^{9}$ The link is: http://www.bea.gov/industry/io benchmark.htm. We select the file labeled '2002 Standard Make and Use Tables at the detailed level'. To calculate the flow between industries, we take ${ }^{1 / 2}{ }^{*}\left(A_{i j}+A_{j i}\right)$ which is the flow in both directions between two NAICS codes. We download a conversion chart from the Census to convert NAICS industries back into SIC codes from: https://www.census.gov/eos/www/naics/concordances/concordances.html. The original file has many I/O codes that do not correspond to NAICS codes, so we manually identify the NAICS code these codes correspond to by using a file provided by the federal government and an examination of the description of each NAICS code.
} 
proportion of connected to non-connected acquirers is higher than average in the utilities, telecommunications, and financial industries. Our finding is consistent with Hillman (2005) and Goldman et al. (2009). It suggests that the knowledge and connections of former politicians and regulators are likely to be more valuable for firms that operate in the heavily regulated environments of public utilities and financial services.

\subsection{Firm Profile Based on Political Connections}

In Table 3 we compare firm characteristics between connected and non-connected acquirers. All variables are winsorized at the 5\% and 95\% levels. From the tests of means in Panel A, we observe that connected acquirers are larger, have more sales, less cash on hand, and are more profitable than non-connected acquirers. These results are consistent with the findings of Goldman et al. (2009). From our test of medians, we find that connected bidders also have higher leverage and market-to-book ratios.

In Panel B we examine the effect that hiring a former politician or regulator has on a future acquirer's performance. We perform a series of difference-in-difference tests. These tests allow us to examine the effect that an increase in political connections has on a firm relative to a control group (Card and Krueger, 1994). We start by identifying the year that the politically connected firm hires a non-general counsel lawyer or former politician, regulator, general, or admiral. We require the hiring date to be no earlier than 1997 . We further eliminate observations in which there are already former politicians or regulators on the firm's board or management team so that we can identify clearly the effect of a firm transitioning from non-connected to connected status. We then match these remaining observations to observations of a control group of firms based on industry classification, year, and closest total assets. We examine the change 
in each of the characteristics from the year prior to the hiring of these connected individuals to the year following the hiring.

Our difference-in-difference tests show that firms which appoint former politicians or regulators to their board or management team experience a much larger change in total sales than the control sample. The percentage growth in the market equity capitalization of the connected firms is less than that of the control firms. But this is hardly surprisingly, given that connected firms are about three times as large as the unconnected acquirers. These findings show that the hiring of former politicians and other connected individuals can influence important aspects of corporate decision making.

\section{Empirical Findings}

\subsection{Political Connections and Acquisition Success}

Managers that intend to acquire merger targets in an attempt to reduce competition face the risk of regulatory denial. A manager can decrease the likelihood of regulatory delay or disapproval by avoiding acquisitions that create barriers to entry or limit industry competition. Firms which enjoy political connections, however, probably have less need to consider these factors when assessing merger targets.

Because managers who make acquisitions that are likely to be denied or delayed have a greater incentive to hire a former politician or regulator, there is a potentially endogenous relation between hiring a former politician and merger litigation. We control for this potential endogeneity between the appointment of connected individuals and the likelihood of merger litigation by using the total Political Action Committee (PAC) contributions made by each acquirer's industry during the election cycle as an instrumented variable for political connections 
in our multivariate analysis. Industries that are heavily regulated and interact more often with government agencies make larger total PAC contributions. Therefore, the PAC contributions made by each industry act as a proxy for the political connectedness of firms in that industry. The PAC contribution measure is uncorrelated with the likelihood of litigation since the industry-level PAC contributions are unrelated to the criteria used by the FTC or the Department of Justice to bring suit. This allows us to use industry-level PAC contributions as an instrumented variable for firm-level political connections.

Our data on PAC contributions is provided by the Federal Election Commission and collected by the Center for Responsive Politics. The vast majority of industries used by the Center for Responsive Politics (CRP) directly align with two-digit SIC codes and can be matched by name. The remaining industries provided by the CRP are matched based on the subcategories associated with the industry. We match each acquirer to the total PAC contributions made by its primary industry based on a two-digit SIC code during the two-year election cycle. We then perform our two-stage least squares regression analysis.

We present our analysis in Table 4. Because the dependent variable is binary we estimate probit models. In Panel A we test the effect of acquirer political connections on merger success. The dependent variable is an indicator variable for incomplete mergers. In all models we control for the probability of making a bid ${ }^{10}$. Columns (1) though (2) and (5) through (6) are estimated for non-diversifying deals. Columns (1), (3), (5), and (7) report results of the first-stage regressions. In models (2), (4), (6), and (8) we present results of the second-stage estimations. In the first stage, we regress our primary measure of political connections, POL1, on industry-

\footnotetext{
${ }^{10}$ We argue the merger completion is determined in two stages. In the first stage the firm makes a bid while in the second stage certain firm characteristics affect deal completion. To condition on the probability of making the bid in a fiscal year, we use entire compustat universe and predict the probability of bid using firm level standard controls. We then include these predicted probabilities in our merger completion models.
} 
election cycle PAC contributions and a set of control variables. In the second stage, we regress an indicator variable for incomplete mergers on our instrumental variable and control variables.

Our results show that acquisitions attempts by politically connected acquirers engaging in non-diversifying deals are less likely to be incomplete. As expected, the instrumental variable, industry-level PAC contributions, is positively correlated with firm-specific political connections. This instrumental variable is negatively correlated to the indicator variable capturing merger incompleteness. The result indicates politically connected acquirers are more likely to close non-diversifying mergers. These results are robust to the elimination of unsolicited and contested bids from the sample. ${ }^{11}$

In Panel B, we examine the relationship between regulatory action and political connections. Specifically, the dependent variable is a binary indicator variable that is equal to one if either the Federal Trade Commission or the Department of Justice files litigation against merger and zero otherwise. In the first stage we regress POL1 on industry-level PAC contributions and find a positive relation. Consistent with our hypothesis, we find in the second stage regressions a negative relation between instrumented PAC contributions and regulatory action during the merger review process for non-diversifying deals.

\subsection{Takeover Premiums}

We propose that connected acquirers are better able to identify targets whose acquisition will result in the acquirer's own value enhancement. That is, connected firms are better able to identify high value targets, perhaps because of the insights, insider information, or access that their political connections provide. Consequently, we believe that these connected acquirers are

\footnotetext{
${ }^{11}$ We also use propensity matching scores to examine the likelihood of connected and non-connected acquirers to complete an acquisition. Our results are quantitatively similar to those contained in Panel A.
} 
willing to pay more for such targets in anticipation of the synergies that their purchase will generate.

In Table 5 we test our conjecture regarding the effects of political connectedness on takeover premia. We use three measures of takeover premiums: (1) PREMMOEL, the measure based on Moeller (2005), (2) PREMISM , the measure based on Ismail (2011), and

(3) PREMBET, the measure based on Betton and Eckbo, (2000). Columns (1), (3), and (5) are estimated for non-diversifying deals while columns (2), (4) and (6) are for the diversifying deals. This table offers strong evidence that political connections positively influences takeover premiums. This result is consistent with political networks helping acquirers to better identify synergy-generating targets.

\subsection{Announcement Period Effects}

In Table 6, we examine the investor response to the announcement of merger bids. Panel A presents the cumulative abnormal returns around the bid announcements. We find that the CARs around bid announcements made by politically connected acquirers are less negative than those made by non-politically connected acquirers. The average three day $(-1,+1)$ return around the bids by politically connected acquirers is $-0.95 \%$ compared to $-1.88 \%$ for non-connected acquirers. Tests of the difference in medians yield quantitatively similar results. These differences are statistically significant.

We believe that the higher market return at the time of acquisition announcement by politically connected firms simply reflects the choice of merger target. That is, these firms simply make better acquisition decisions, resulting in higher CARs. This might be due to the unique insights regarding issues such as regulatory process and delay, government contracting needs and procedures, or pending legislation that these political connections provide. These 
insights allow the connected firm to make better choices regarding acquisition. Thus the market responds to the superior choice of target (which is new information) made by the connected firm rather than their political connections (which is old information).

Next we examine the returns around the announcements of horizontal, vertical, and nondiversifying acquisitions. In Panels B we observe that the negative response to a horizontal acquisition by non-connected acquirers, $-2.07 \%$, is almost double that of announcements made by connected acquirers (i.e., $-1.17 \%$ ). Panel C shows that for the vertical acquisitions the announcement returns are usually less negative for connected acquirers, thought the difference is only significant when we use POL3 and event window (day -1 through day 0). In Panel D, we find that even when politically connected acquirers make non-diversifying bids, investors respond less negatively to the news. In the three-day period surrounding the announcement (day -1 through day +1 ), shares of politically connected acquirers decline by $-1.16 \%$ compared to a fall of $-2.02 \%$ for non-connected acquirers.

In the multivariate analysis presented in Panel E, we regress the value-weighted cumulative abnormal return upon our measures of political connections, our set of control variables, and year/industry fixed effects. We find a positive relation between cumulative abnormal returns and political connections.

In Table 7, we examine the relation between political connections and the equity market's response to resolution of regulatory uncertainty. The Federal Trade Commission and the Department of Justice generally have thirty days to decide whether or not to approve a potential deal. ${ }^{12}$ If the merger review period is terminated early, this resolution of uncertainty can increase the share prices of the merger parties. Further, it might be that the political connections of the

\footnotetext{
${ }^{12}$ If other agencies are involved in the review process, the merger review period can be extended.
} 
acquirer influence the decision of these federal regulators to terminate the deal's review and allow it to proceed.

We present our empirical findings concerning the merger review period in Panel A of Table 7. We find the share price response to early termination announcements is more positive for non-connected acquirers. During the (day -5 through day +5 ) window surrounding the resolution of uncertainty, we find cumulative abnormal returns of $-1.18 \%$ for politically connected acquirers, compared with $0.85 \%$ for non-connected acquirers. The positive reaction around the early termination date of non-connected acquisitions implies that there is greater uncertainty concerning these acquisitions during the merger review process.

In Panel B, we examine the cumulative abnormal returns of connected and nonconnected acquirers around the resolution of merger litigation. If investors are less uncertain regarding the outcome of litigation against connected acquirers, then the share price response at the time of resolution should be lower for them. We find that the ten-day value-weighted abnormal return around the resolution of merger litigation is $0.75 \%$ for non-connected firms, but $-0.68 \%$ for connected firms. The result is significant at the $5 \%$ level. This result is robust to different return windows, the use of raw and equal-weighted returns, and more inclusive measures of political connections (i.e.,POL2, POL3).

In Panel C, we examine the relation between an acquirer's political connections and the abnormal return around the resolution of merger litigation with a multivariate model. We regress cumulative abnormal returns against POL1 and a series of control variables. We find a significantly negative relation between political connections and the firm's cumulative abnormal returns. These findings confirm the results reported previously in Panels A and B. Investors are 
less uncertain regarding the outcome of the merger review process when acquirers maintain political connections.

The results from Tables 4, 6, and 7 show that connected acquirers are more likely to complete an acquisition and are less likely to face regulatory action from U.S. merger regulators. When these firms face litigation, investors anticipate that the cost of such litigation is lower for these firms. These results imply that managers of connected firms should be more willing to make bids for merger targets that might attract regulatory attention or disapproval. This further implies that connected acquirers are more likely to pursue those larger targets which will attract greater regulatory scrutiny.

\subsection{Acquisition Activity and Target Size of Politically Connected Acquirers}

In this section we examine the general nature of acquisition activity by connected acquirers. Specifically, we examine the number of bids made by connected firms as well as the size of the target. We anticipate that both are positively related to the political connectivity of the firm.

In Panel A of Table 8, we regress the natural logarithm of the number of total bids and acquisitions each firm makes on various measures of bidder/acquirer political connections, a set of control variables, and year/industry fixed effects. We find a positive relation between the political connections of the bidding firm and the number of bids the firm makes. In Models 4, 5, and 6, we examine the number of acquisitions of public targets made by the sample acquirers. We find that connected firms make more public acquisitions than non-connected firms. The same results persist in Panel B when we examine only non-diversifying bids and acquisitions ${ }^{13}$.

\footnotetext{
${ }^{13}$ We repeat the analysis using Tobit regression since the number of bids is truncated at zero. We find qualitatively similar results.
} 
We perform difference-in-difference tests in Panel C to address potential endogeneity between the size of the acquirer and the acquirer's ability to attract politically connected individuals. We use the matched sample described in Panel B of Table 3 for our analysis. The results in column two of Panel C represent the difference in the number of bids during the period after the hiring of that connected individual and the number of bids during the period before the hiring of the connected individual. In column three we examine the change in the number of bids made by the control firms over the same period. Firms that hire connected individuals make 0.56 more public bids over the three years following the appointment than the three years prior to the appointment. Firms that hire a connected individual make 0.52 more total bids in the three years after the appointment than in the three years prior to the appointment. The control firms increase the number of bids by 0.04 and 0.01 over the same period. We report the p-value for the difference in the differences in column four. Our results are statistically for each of the difference-in-difference tests. These findings suggest that firms which hire former politicians or regulators increase the number of bids they make for both public and private targets, even after controlling for past acquisition activity and firm characteristics. We perform additional difference-in-difference tests in Panel D using alternative event windows and still obtain convincing evidence in support of our main conjectures.

Next we examine the relation between the political connections and target size. In Models 1, 2, and 3 of Table 9, we measure size as the market capitalization of the acquirer. We find a positive relation between an acquirer's political connections and target size. In Models 4, 5 , and 6, our dependent variable is the total assets of the target. We find a positive relation between target total assets and acquirer political connections. Finally in Models 7, 8, and 9, we 
find a positive relation between the target's total sales and the political connections of the acquirer.

Together, the results in Tables 8 and 9 show that politically connected acquirers make larger and more frequent merger bids/acquisitions. These findings imply that acquirers with politically connected directors exploit their insider knowledge of the regulatory process and network contacts by pursuing more mergers and bidding on larger targets.

\subsection{Post-Merger Performance of Politically Connected Firms}

In this section we test our last hypothesis and seek to determine if acquirers with political connections purchase targets that provide them with long-term value. To calculate long-term equity-based performance, we use the buy-and-hold abnormal return approach of Mitchell and Stafford (2000).

In Table 10, we examine the post-merger financial performance of the acquirers most likely to benefit from political connections. These are the firms which make non-diversifying acquisition during the first five years following the merger. We focus on the abnormal returns associated with non-diversifying acquisitions because the knowledge that former politicians or regulators provide is most valuable when structuring horizontal or vertical acquisitions. These mergers are also the most likely to be opposed because they have the greatest potential to increase industry or market concentration.

Our results in Panel A of Table 10 show that non-politically connected acquirers exhibit higher returns over the five years after the month in which the merger becomes effective. These results are most robust for the strongest political connections and weaken when we consider the wider, but more diluted measures of political connections (i.e., POL2, POL3). 
We regress cumulative abnormal returns on POL1, control variables, and year and industry fixed effects in Panel B. We find significantly positive relationship between POL1 and the dependent variables indicating that politically connected acquirers have abnormal returns superior to those of non-connected acquirers.

We examine the post-merger accounting performance of our acquirer sample in Table 11. We use the IAROA (industry-adjusted return on assets) approach of Wang and Xie (2009). In Panel A, we report the mean industry-adjusted ROA and change in industry-adjusted ROA for connected and non-connected acquirers. In Panel B, we regress the industry-adjusted ROA on POL1, control variables, and year and industry fixed effects. As in Table 10, we report the results for only the non-diversifying acquirers since these firms should benefit the most from political connections.

Politically connected acquirers are more profitable than non-connected acquirers after the acquisition. In the year after the acquisition, connected acquirers have an industry-adjusted ROA of $2.46 \%$ compared to $-0.51 \%$ for non-connected acquirers. This difference remains mostly significant when we use POL2 or POL3 as alternative measures of political connections. This suggests that firms that hire former politicians or regulators are able to use their knowledge to avoid unprofitable or poorly-fitting targets. Our results in Panel B confirm the univariate findings reported in Panel A.

\section{A Further Control for Endogeneity}

Our findings in the previous section could be contaminated by endogeneity. As we discussed above, we use instrumental variable approach and difference-in-difference framework to address these issues. We also include a number of acquirer, target, and deal characteristics in 
our models to mitigate the concern that the omitted variables could drive the results. The above notwithstanding, skeptical readers might argue unobserved time-invariant characteristic could still bias the documented relationships. Consequently, we run robustness checks by estimating our models using firm fixed effects.

Using firm fixed effects identification in our empirical framework has its own limitation since we do not use traditional panel data. Firms are included in the sample only if they engage in M\&A activities. A number of firms appear only one time in the sample. It is possible for our sample firms to engage in mergers more than once during the sample period (and even during the same year) and in these cases we have panels since firms are included several times in the sample for different years. However, fixed-effects models rely exclusively on within-subject variations to identify the effects of explanatory variables. That is, in our case, firm fixed effects identification requires time series variations in our main political connectedness measures. But these variables do not vary much from year to year, though we still observe some variations in or sample.

Nevertheless, we estimate our models using firm fixed effects. For the sake of brevity we do not provide separate tabulation of our findings. We find that our results are consistent with those reported in this study. Further, they are generally statistically significant. We conclude from this analysis that our models do not suffer from limitations attributable to unobserved time invariant characteristics.

\section{Conclusion}

The goal of this study is to examine how corporate political connections effect the merger process in the United States. We examine the effect that the addition of a politically connected 
individual to a firm's management team/board of directors has on the merger behavior of a sample of publicly traded companies. We hypothesize that acquiring firms which enjoy political connections are better able to navigate the regulatory barriers constructed by the federal agencies which control the merger process. As a result, these acquirers are likely to make a greater number of bids and pursue larger targets. Further, connected acquirers might make better merger choices given the unique insights and private information that their political connections can provide. This implies higher announcement period returns for these firms. Finally, we test whether these connected acquirers enjoy superior performance following their merger.

Our results are consistent with our hypotheses. We find that connected firms make more bids and acquisitions than non-connected acquirers. Indeed, we find that the increase in bid and acquisition activity follows after former politicians or regulators are appointed to a firm's board or management team. We also observe that firms with stronger political connections acquire larger targets. This result holds regardless of whether we measure size by equity capitalization, total assets, or gross sales.

Investors also respond more positively to the bid announcements made by politically connected acquirers, suggesting that they anticipate the firm to obtain greater value from their acquisition. We believe that this result reflects the superior choice of merger target by these connected acquirers. This might be due to the unique insights regarding issues such as regulatory process and delay, government contracting needs and procedures, or pending legislation that these political connections can provide to the acquiring firm. This interpretation is confirmed with the higher premiums that the connected acquirer pays. That is, after identifying a superior target, the acquirer pays a higher price for them. 
We also explore whether acquisitions by connected firms provide superior post-merger financial and accounting performance. We discover that connected acquirers exhibit higher five-year abnormal returns as well as industry-adjusted return on assets than non-connected acquirers. These results support our hypothesis that firms which hire former politicians or regulators enjoy a higher level of operating performance. This might be due to their use of the private information and lobbying access which such individuals can offer to their new corporate employer. We conclude that political connections are valuable for acquirers and allow them to better position themselves during the regulatory review process. This ultimately results in a stronger operating performance for these firms.

Although this study makes important contributions to our understanding of how political connections influence the strategically critical decision about mergers, there are limitations to it which provide opportunities for future research. Although we demonstrate the importance of political connections, it is less clear what mechanisms account for these results. Former government officials can provide insider knowledge about regulatory procedures, facilitate access to current regulators, or engage in personal lobbying. In this study, however, we are unable to disentangle which specific channel or technique is most effective in advancing the acquirer's interest. Future research using network based data might prove fruitful towards a more complete understanding of this issue. It is also unclear whether our findings hold for acquisitions outside the United States. Acquirers in countries with weaker institutions are less likely to face antitrust litigation and hence have less need for political connections to gain merger approval. Again, future research focusing on the structure of a country's political economy is likely to produce important insights into the relation between corporate political connections and market structure. Finally, this analysis does not speak about optimal or most effective board design. Our 
findings seem to suggest that firms with former regulators or politicians as directors or manages can benefit from such appointments. Thus future research about board construction and effectiveness might want to consider to what extent political connections are important for the firm's strategic success. 


\section{References}

Acemoglu, D., Johnson, S., Mitton, T., 2009. Determinants of vertical integration: financial development and contracting costs. J. Financ. 64 (3), 1251-1290.

Bebchuk, L.A., Cohen, A., Ferrell, A., 2009. What matters in corporate governance? Rev. Financ. Stud. 22 (2), 783-827.

Betton, S., Eckbo, B.E., 2000 Toeholds, bid jumps, and expected payoffs in takeovers. Rev. Financ. Stud. 13 (4), 841-882.

Boubakri, N., Guedhami, O., Mishra, D., Saffar, W., 2012. Political Connections and the cost of equity capital. J. Corp. Financ. 18 (3), 541-559.

Bradley, M., Desai, A., Kim, E.H., 1988. Synergistic gains from corporate acquisitions and their division between the stockholders of target and acquiring firms. J. Financ. Econ. 21 (1), 3-40.

Brezis, E.S., Paroush, J., Weiss A., 2002. Red Tape: Oiling the Hinges of the Revolving Door. Working Paper.

Card, D., Krueger, A.B., 1994, Minimum wages and employment: A case study of the fast-food industry in New Jersey and Pennsylvania. Am. Econ. Rev. 84 (4), 772-793.

Cornaggia, J., Cornaggia, K.J., Xia, H., 2016. Revolving doors on Wall Street. J. Financ. Econ. 120 (2), 400-419.

Crawford, D., Lechner, T., 1996. Takeover premiums and anticipated merger gains in the US market for corporate control. J. Bus. Financ. Acc. 23 (7), 807-829.

Croci, E., Pantzalis, C., Park, J.C., Petmezas, D., 2016. The role of corporate political strategies in M\&As. Working Paper.

Duchin, R., Schmidt, B., 2013. Riding the merger wave: Uncertainty, reduced monitoring, and bad acquisitions. J. Financ. Econ. 107 (1), 69-88.

Egge, M.G., Cruise, J.D., 2014. Practical guide to the U.S. merger review process. Retrieved from https://www.lw.com/thoughtleadership/practical-guide-us-merger-review-process-012014.

Faccio, M., 2006. Politically connected firms. Am. Econ. Rev. 96 (1), 369-386.

Fan, J.P., Goyal, V.K., 2006. On the patterns and wealth effects of vertical mergers. J. Bus. 79 (2), 877-902.

Fuller, K., Netter, J., Stegemoller, M., 2002. What do returns to acquiring firms tell us? Evidence from firms that make many acquisitions. J. Financ. 57 (4), 1763-1793.

Goldman, E., Rocholl, J., So, J., 2009. Do politically connected boards affect firm value? Rev. Financ. Stud. 22 (6), 2331-2360.

Harford, J., 2005. What drives merger waves? J. Financ. Econ. 77 (3), 529-560. 
Hillman, A.J., 2005. Politicians on the board of directors: Do connections affect the bottom line? J. Manag. 31 (3), 464-481.

Hillman, A.J., Keim, G.D., Schuler, D., 2004. Corporate political activity: A review and research agenda. J. Manag. 30 (6), 837-857.

Ismail, A., 2011. Does the management's forecast of merger synergies explain the premium paid, the method of payment, and merger motives? Financ. Manag. 40 (4), 879-910.

Mitchell, L.M., Stafford, E., 2000. Managerial decisions and long-term stock price performance. J. Bus. 73 (3), 287-329.

Moeller, T., 2005. Let's make a deal! How shareholder control impacts merger payoffs. J. Financ. Econ. 76 (1), 167-190.

Monardi, F., Glantz, S.A., 1998. Are tobacco industry campaign contributions influencing state legislative behavior? Am. J. Pub. Health. 88 (6), 918-923.

Mulherin, J.H., Boone, A., 2000. Comparing acquisitions and divestitures. J. Corp. Financ. 6 (2), 117-129.

Roll, R., 1986. The hubris hypothesis of corporate takeovers. J. Bus. 59 (2), 197-216

Salamon, L.M., Siegfried, J.J., 1977. Economic power and political influence: The impact of industry structure on public policy. Am. Pol. Sci. Rev. 71 (03), 1026-1043.

Stratmann, T., 2002. Can special interests buy congressional votes? Evidence from financial services legislation. J. Law Econ. 45 (2), 345-373.

Varaiya, N.P., 1987. Determinants of premiums in acquisition transactions. Manag. Dec. Econ. 8 (3), 175-184.

Wang, C. Xie, F., 2009. Corporate governance transfer and synergistic gains from mergers and acquisitions. Rev. Financ. Stud. 22 (2), 829-858. 


\section{Table 1: The Nature of Merger Activity}

Panel A of this table compares the difference in the average number bids and acquisitions. Vertical bids and acquisitions are defied following Acemoglu et al. (2009). Horizontal mergers are as those in which the acquirer and target share the same primary SIC code. Panel B contains a time-series distribution of the sample. PC indicates politically connected firms. NPC indicates non-politically connected firms. Firms which are politically connected according to POL1 have at least one member of the board of directors or a manager who is a former politician or regulator. POL2 defines politically connected firms as those firms which have a former politician, regulator on their board or management team, or former senior member of the military. POL3 defines politically connected firms as those firms which have a former politician, regulator, senior military officer, or lawyer on the board or management team. ${ }^{*}$,*, and ${ }^{* * *}$ denote significance at the $10 \%, 5 \%$, and $1 \%$ levels.

\section{Panel A: Number of Bids and Acquisitions}

\begin{tabular}{|c|c|c|c|c|c|c|c|c|c|c|c|c|}
\hline & & & POL1 & & & & POL2 & & & & POL3 & \\
\hline & PC & NPC & Difference & P-value & PC & NPC & Difference & P-value & $\mathrm{PC}$ & NPC & Difference & P-value \\
\hline Public bids & 1.272 & 1.161 & $0.111^{* * *}$ & $(0.000)$ & 1.262 & 0.164 & $1.098 * * *$ & $(0.001)$ & 1.286 & 1.099 & $0.187 * * *$ & $(<.0001)$ \\
\hline Public acquisitions & 1.270 & 1.149 & $0.121 * * *$ & $(<.0001)$ & 1.26 & 1.152 & $0.108 * * *$ & $(0.000)$ & 1.285 & 1.081 & $0.204 * * *$ & $(<.0001)$ \\
\hline Horizontal bids & 1.152 & 1.086 & $0.066^{* *}$ & $(0.028)$ & 1.148 & 1.087 & $0.061 * *$ & $(0.040)$ & 1.142 & 1.072 & $0.070 * *$ & $(0.012)$ \\
\hline Horizontal acquisitions & 1.150 & 1.084 & $0.066 *$ & $(0.042)$ & 1.147 & 1.085 & $0.062 *$ & $(0.054)$ & 1.147 & 1.064 & $0.083 * * *$ & $(0.005)$ \\
\hline Vertical bids & 1.200 & 1.198 & 0.002 & $(0.980)$ & 1.19 & 1.204 & -0.014 & $(0.863)$ & 1.273 & 1.11 & $0.163^{* *}$ & $(0.033)$ \\
\hline Vertical acquisitions & 1.179 & 1.196 & -0.017 & $(0.837)$ & 1.169 & 1.202 & -0.033 & $(0.689)$ & 1.241 & 1.123 & 0.118 & $0.144)$ \\
\hline
\end{tabular}

\section{Panel B: Time-Series Distribution of the Sample}

\begin{tabular}{|c|c|c|c|c|c|c|c|}
\hline \multirow[t]{2}{*}{ Year } & \multirow[t]{2}{*}{$\mathrm{N}$} & \multicolumn{2}{|c|}{ POL1 } & \multicolumn{2}{|c|}{ POL2 } & \multicolumn{2}{|c|}{ POL3 } \\
\hline & & PC & NPC & PC & NPC & PC & NPC \\
\hline 1997 & 148 & 48 & 100 & 51 & 97 & 82 & 66 \\
\hline 1998 & 168 & 51 & 117 & 54 & 114 & 84 & 84 \\
\hline 1999 & 191 & 74 & 117 & 76 & 115 & 104 & 87 \\
\hline 2000 & 162 & 47 & 115 & 48 & 114 & 76 & 86 \\
\hline
\end{tabular}




\begin{tabular}{|c|c|c|c|c|c|c|c|}
\hline & & & & & & \\
\hline 2001 & 141 & 41 & 100 & 42 & 99 & 71 & 70 \\
\hline 2002 & 78 & 19 & 59 & 21 & 57 & 45 & 33 \\
\hline 2003 & 83 & 23 & 60 & 25 & 58 & 42 & 41 \\
\hline 2004 & 94 & 20 & 74 & 22 & 72 & 47 & 47 \\
\hline 2005 & 91 & 39 & 52 & 39 & 52 & 49 & 42 \\
\hline 2006 & 101 & 41 & 60 & 42 & 59 & 57 & 44 \\
\hline 2007 & 103 & 36 & 67 & 39 & 64 & 54 & 49 \\
\hline 2008 & 84 & 35 & 49 & 36 & 48 & 48 & 36 \\
\hline 2009 & 55 & 20 & 35 & 20 & 35 & 30 & 25 \\
\hline 2010 & 81 & 27 & 54 & 28 & 53 & 42 & 39 \\
\hline 2011 & 47 & 17 & 30 & 18 & 29 & 27 & 20 \\
\hline 2012 & 65 & 30 & 35 & 31 & 34 & 40 & 25 \\
\hline 2013 & 60 & 27 & 33 & 27 & 33 & 36 & 24 \\
\hline Total & 1752 & 595 & 1157 & 619 & 1133 & 934 & 818 \\
\hline
\end{tabular}




\section{Table 2: Sample Distribution by Industry and Political Connections}

This table presents descriptive statistics of the acquirer political connectedness by Fama-French 12 industries. PC indicates politically connected firms. NPC indicates non-politically connected firms. Firms that are politically connected according to the first political connectedness measure (POL1) have at least one member of the board of directors or a manager who is a former politician or regulator. POL2 equals one if the firm has a former politician, regulator, or member of the military on their board or management team and equals zero otherwise. POL3 equals one if the firm has a former politician, regulator, member of the military, or non-general counsel lawyer on their board or management team and equals zero otherwise. Regulated firms are defined as firms with SIC codes 4000-4999 or 6000-6999.

\begin{tabular}{|c|c|c|c|c|c|c|c|c|}
\hline \multicolumn{3}{|c|}{ Fama-French Industries } & \multicolumn{2}{|c|}{ POL1 } & \multicolumn{2}{|c|}{ POL2 } & \multicolumn{2}{|c|}{ POL3 } \\
\hline & & & PC & NPC & PC & NPC & PC & NPC \\
\hline 1 & NoDur & Consumer NonDurables & 23 & 32 & 23 & 32 & 29 & 26 \\
\hline 2 & Durbl & Consumer Durables & 8 & 16 & 10 & 14 & 15 & 9 \\
\hline 3 & Manuf & Manufacturing & 49 & 83 & 51 & 81 & 62 & 70 \\
\hline 4 & Enrgy & Oil, Gas, and Coal Extraction and Products & 27 & 46 & 27 & 46 & 41 & 32 \\
\hline 5 & Chems & Chemicals and Allied Products & 8 & 21 & 8 & 21 & 11 & 18 \\
\hline 6 & BusEq & Business Equipment & 146 & 377 & 159 & 364 & 223 & 300 \\
\hline 7 & Telcm & Telephone and Television Transmission & 33 & 24 & 33 & 24 & 43 & 14 \\
\hline 8 & Utils & Utilities & 23 & 23 & 23 & 23 & 35 & 11 \\
\hline 9 & Shops & Wholesale, Retail, and Some Services & 36 & 67 & 38 & 65 & 50 & 53 \\
\hline 10 & Hlth & Healthcare, Medical Equipment, and Drugs & 86 & 106 & 89 & 103 & 110 & 82 \\
\hline 11 & Money & Finance & 122 & 275 & 123 & 274 & 258 & 139 \\
\hline \multirow[t]{4}{*}{12} & Other & Other & 34 & 87 & 35 & 86 & 57 & 64 \\
\hline & & Regulated Industries & 145 & 298 & 146 & 297 & 293 & 150 \\
\hline & & Unregulated Industries & 450 & 859 & 473 & 836 & 641 & 668 \\
\hline & Total & & 595 & 1157 & 619 & 1133 & 934 & 818 \\
\hline
\end{tabular}




\section{Table 3: Comparative Characteristics of Sample Firms}

Panel A provides a comparison of mean and median financial characteristics of politically connected and non-connected acquirers. Panel B contains the results from a difference-in-difference test. PC indicates politically connected firms that have at least one member of the board of directors or a manager who is a former politician or regulator (POL1). NPC indicates non-politically connected firms. MCAP refers to equity market capitalization, TA is total assets, SALES are annual gross sales, CASHTA is the ratio of the firm's cash to total assets, ROA is return on assets, DEBTTA is the ratio of total debt to total assets, and MB is the equity market to book ratio. *, **, and *** denote significance at the $10 \%, 5 \%$, and $1 \%$ levels.

\section{Panel A: Politically Connected vs. Non-Connected Firms}

\begin{tabular}{|c|c|c|c|c|c|c|c|c|}
\hline & \multicolumn{4}{|c|}{ Mean } & \multicolumn{4}{|c|}{ Median } \\
\hline & $\mathrm{PC}$ & NPC & Difference & P-value & $\mathrm{PC}$ & NPC & Difference & P-value \\
\hline MCAP & 30779.02 & 9408.01 & $21371.010 * * *$ & $(<.0001)$ & 6892.27 & $1408.98 * * *$ & 5483.290 & $(<.0001)$ \\
\hline TA & 29539.65 & 12721.77 & $16817.880 * * *$ & $(<.0001)$ & 7544.77 & $1385.99 * * *$ & 6158.780 & $(<.0001)$ \\
\hline SALE & 15492.62 & 4072.69 & $11419.930 * * *$ & $(<.0001)$ & 4248.79 & $620.967 * * *$ & 3627.823 & $(<.0001)$ \\
\hline CASHTA & 0.086 & 0.111 & $-0.025 * * *$ & $(<.0001)$ & 0.046 & 0.057 & $-0.011 * * *$ & $(0.003)$ \\
\hline ROA & 0.05 & 0.018 & $0.032 * * *$ & $(<.0001)$ & 0.046 & $0.034^{* * *}$ & 0.012 & $(<.0001)$ \\
\hline DEBTTA & 0.176 & 0.17 & 0.006 & $(0.474)$ & 0.144 & $0.109 * * *$ & 0.035 & $(0.0012)$ \\
\hline MB & 7.365 & 4.181 & 3.184 & $(0.206)$ & 2.68 & $2.439 *$ & 0.241 & $(0.0671)$ \\
\hline
\end{tabular}

\section{Panel B: Difference-in-Difference Tests}

\begin{tabular}{|c|c|c|c|c|c|c|c|c|}
\hline \multicolumn{5}{|c|}{ Mean } & \multicolumn{4}{|c|}{ Median } \\
\hline & $\mathrm{PC}$ & NPC & Difference & P-value & $\mathrm{PC}$ & NPC & Difference & P-value \\
\hline MCAP & $13.60 \%$ & $29.90 \%$ & $-16.30 \% * *$ & $(0.021)$ & $20.40 \%$ & $16.90 \%$ & $3.50 \%$ & $(0.265)$ \\
\hline $\mathrm{TA}$ & $44.80 \%$ & $33.60 \%$ & $11.20 \%$ & $(0.166)$ & $22.80 \%$ & $17.00 \%$ & $5.80 \%$ & $(0.129)$ \\
\hline SALE & $48.80 \%$ & $21.40 \%$ & $27.40 \% * * *$ & $(0.003)$ & $20.50 \%$ & $13.60 \%$ & $6.90 \% * *$ & $(0.033)$ \\
\hline
\end{tabular}




\begin{tabular}{lllllllll}
\hline CASHTA & $45.38 \%$ & $49.45 \%$ & $-4.07 \%$ & $(0.797)$ & $3.08 \%$ & $-1.9 \%$ & $4.98 \%$ & $(0.529)$ \\
ROA & $-31.50 \%$ & $-45.60 \%$ & $14.10 \%$ & $(0.461)$ & $-7.50 \%$ & $-20.60 \%$ & $13.10 \%$ & $(0.259)$ \\
DEBTTA & $17.10 \%$ & $23.50 \%$ & $-6.40 \%$ & $(0.561)$ & $0.80 \%$ & $-7.90 \%$ & $8.70 \% *$ & $(0.060)$ \\
MB & $2.60 \%$ & $7.70 \%$ & $-5.10 \%$ & $(0.393)$ & $-0.80 \%$ & $1.00 \%$ & $-1.80 \%$ & $(0.529)$ \\
\hline
\end{tabular}




\section{Table 4: Probability of Merger Success and Regulatory Action}

This table report results of the 2-SLS IV regressions. Columns (1), (3), (5), and (7) report results of the following first-stage:POL1 $1_{i t}=\beta_{0}+\beta_{1} P A C_{i, t}+$ $\beta_{2}$ RELSIZE $_{i, t}+\beta_{3}$ ACQSIZE $_{i, t}+\beta_{4}$ ACQROA $_{i, t}+\beta_{5}$ ACQMB $_{i, t}+\beta_{6}$ ACQLEV $_{i, t}+\beta_{7}$ TARSIZE $_{i, t}+\beta_{8}$ TARROA $_{i, t}+\beta_{9}$ TARMB $_{i, t}+\beta_{10}$ CASH $_{i, t}+$ $\beta_{11}$ VERTICAL $_{i, t}+\beta_{12}$ TENDOFFER $_{i, t}+\beta_{13}$ COMPDEAL $_{i, t}++\beta_{14}$ HOSTDEAL $_{i, t}+$ YearDummies $+\varepsilon_{i, t}$, where POL1 indicates whether the bidder has a former politician or industry regulator on its board or management team, $P A C$ is an instrumental variable estimate as the total political action committee contributions made by each acquirer's industry during the election cycle, and RELSIZE is acquirer market capitalization scaled by target market capitalization. Acquirer (target) characteristics include: ACQ(TAR)SIZE - market capitalization, ACQ(TAR)ROA - return on assets estimated as is the ratio of operating earnings to firms' total assets, $A C Q(T A R) M B$ - market-to-book ratio estimated as the market value of equity divided by book value, $A C Q L E V$ - total debt scaled by total assets. Deal characteristics include: CASH, VERTICAL, TENDOFFER, COMPDEAL, and HOSTILEDEAL - dummy variables that take value one if the transaction includes a cash component, if the acquisition is vertical according to Acemoglu et al. (2009), if it is a tender-offer, if there is more than one bidder, and if it is hostile according to SDC, respectively. Columns (2), (4), (6), and (8) report results of the following second-stage regression: $Y_{i t}=\beta_{0}+\beta_{1} \widehat{P O L 1}_{i, t}+$ $\beta_{2}$ RELSIZE $_{i, t}+\beta_{3}$ ACQSIZE $_{i, t}+\beta_{4}$ ACQROA $_{i, t}+\beta_{5}$ ACQMB $_{i, t}+\beta_{6}$ ACQLEV $_{i, t}+\beta_{7}$ TARSIZE $_{i, t}+\beta_{8}$ TARROA $_{i, t}+\beta_{9}$ TARMB $_{i, t}+\beta_{10}$ TARLEV $_{i, t}+$ $\beta_{11}$ CASH $_{i, t}+\beta_{12}$ VERTICAL $_{i, t}+\beta_{13}$ TENDOFFER $_{i, t}+\beta_{14}$ COMPDEAL $_{i, t}++\beta_{15}$ HOSTDEAL $_{i, t}+$ YearDummies $+\varepsilon_{i, t}$. In Panel A the dependent variable $Y_{i, t}$ is an indicator variable for incomplete mergers. $P R O B(B I D)$ - the probability of making the bid in a fiscal year is added as a control. In Panel B the dependent variable $Y_{i, t}$ is a dummy variable that takes the value of one if either the FTC or the DOJ file merger litigation. In Columns (5)-(8) the following controls are added for the acquirer: ACQ E-INDEX, ACQ INDDIR, ACQBSIZE, ACQDUAL, ACQINST, and AQCHERF - entrenchment index from Bebchuk et al. (2009), proportion of independent directors, board size, CEO/Chairman duality, institutional ownership, and the Herfindahl index of industry concertation based on sale, respectively. For the target TARLEV- total debt scaled by total assets, TARHERF - Herfindahl index of industry concertation based on sale, RUNUP - target share price runup from $t-230$ to $t-11$ days prior to the bid announcement are added. Columns (1)-(2), and (5)-(7) are estimated for nondiversifying deals. White's heteroscedasticity-robust standard errors are shown in parentheses. *, **, and $* * *$ indicate significance at the $10 \%, 5 \%$, and $1 \%$ levels, respectively.

\section{Panel A: Probability of Acquisition Success}

\begin{tabular}{|c|c|c|c|c|c|c|c|c|}
\hline & (1) & $(2)$ & (3) & (4) & (5) & (6) & (7) & (8) \\
\hline & \multicolumn{2}{|c|}{ Non-Diversifying } & \multicolumn{2}{|c|}{ Diversifying } & \multicolumn{2}{|c|}{ Non-Diversifying } & \multicolumn{2}{|c|}{ Diversifying } \\
\hline & $1^{\text {st }}$ Stage & $2^{\text {nd }}$ Stage & $1^{\text {st }}$ Stage & $2^{\text {nd }}$ Stage & $1^{\text {st }}$ Stage & $2^{\text {nd }}$ Stage & $1^{\text {st }}$ Stage & $2^{\text {nd }}$ Stage \\
\hline \multirow[t]{2}{*}{ PAC } & $0.035 * * *$ & & -0.001 & & $0.050 * *$ & & 0.036 & \\
\hline & $(0.0133)$ & & (0.0139) & & $(0.0200)$ & & (0.0219) & \\
\hline$\widehat{\text { POL1 }}$ & & $-2.966 * *$ & & 1.560 & & $-2.798 *$ & & 2.087 \\
\hline
\end{tabular}



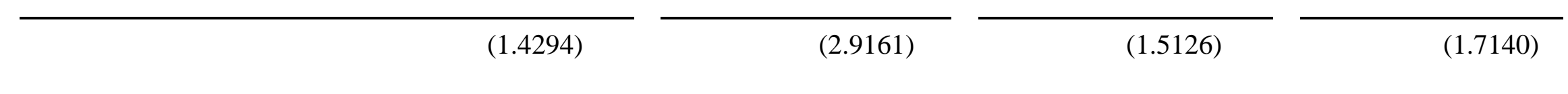

Acquirer Characteristics

\begin{tabular}{|c|c|c|c|c|c|c|c|c|}
\hline \multirow[t]{2}{*}{ RELSIZE } & -0.066 & 0.080 & $-0.897 * * *$ & 1.025 & -0.024 & -0.348 & $-0.824 *$ & 0.914 \\
\hline & $(0.2262)$ & $(0.2681)$ & $(0.2693)$ & $(0.7891)$ & $(0.3970)$ & $(0.5427)$ & $(0.4228)$ & $(0.6307)$ \\
\hline \multirow[t]{2}{*}{ ACQSIZE } & $0.014^{* * *}$ & 0.008 & 0.002 & -0.005 & $0.016 * * *$ & 0.001 & 0.004 & -0.002 \\
\hline & $(0.0035)$ & $(0.0081)$ & $(0.0023)$ & $(0.0048)$ & $(0.0048)$ & $(0.0129)$ & $(0.0035)$ & $(0.0055)$ \\
\hline \multirow[t]{2}{*}{ ACQROA } & 0.703 & -0.321 & 0.399 & 1.196 & -0.429 & 2.639 & $-3.002 * *$ & 2.383 \\
\hline & $(0.6872)$ & (0.8739) & $(0.7732)$ & (1.0278) & $(1.2401)$ & (1.6816) & (1.4938) & $(2.6036)$ \\
\hline \multirow[t]{2}{*}{ ACQMB } & -0.020 & 0.003 & 0.004 & 0.022 & -0.014 & 0.019 & $0.056^{*}$ & 0.010 \\
\hline & $(0.0207)$ & $(0.0284)$ & $(0.0210)$ & $(0.0266)$ & $(0.0308)$ & $(0.0461)$ & $(0.0311)$ & $(0.0471)$ \\
\hline \multirow[t]{2}{*}{ ACQLEV } & 0.399 & -0.105 & -0.074 & -0.567 & 0.775 & -0.403 & -0.646 & 0.058 \\
\hline & $(0.3369)$ & $(0.4619)$ & $(0.3592)$ & $(0.4451)$ & $(0.5859)$ & $(0.9766)$ & $(0.5700)$ & $(0.8036)$ \\
\hline \multirow[t]{2}{*}{ ACQ E-INDEX } & & & & & -0.064 & $-0.216^{*}$ & $-0.115^{*}$ & 0.116 \\
\hline & & & & & $(0.0688)$ & $(0.1313)$ & $(0.0674)$ & (0.1109) \\
\hline \multirow[t]{2}{*}{ ACQ INDDIR } & & & & & $0.962 *$ & 0.455 & $0.835^{*}$ & -0.655 \\
\hline & & & & & $(0.5001)$ & $(0.8812)$ & $(0.4870)$ & $(0.7814)$ \\
\hline \multirow[t]{2}{*}{ ACQBSIZE } & & & & & $0.061^{* *}$ & 0.047 & 0.015 & -0.060 \\
\hline & & & & & $(0.0286)$ & $(0.0588)$ & $(0.0248)$ & $(0.0388)$ \\
\hline \multirow[t]{2}{*}{ ACQDUAL } & & & & & 0.179 & -0.172 & -0.085 & -0.248 \\
\hline & & & & & $(0.1905)$ & $(0.2792)$ & (0.1933) & $(0.2039)$ \\
\hline
\end{tabular}




\begin{tabular}{|c|c|c|c|c|c|c|c|c|}
\hline \multirow[t]{2}{*}{ ACQINST } & & & & & 0.826 & 0.411 & $1.243^{*}$ & -0.545 \\
\hline & & & & & $(0.7238)$ & (0.9983) & $(0.7429)$ & (1.2025) \\
\hline \multirow[t]{2}{*}{ ACQHERF } & & & & & $0.651^{* *}$ & -0.429 & 0.214 & -0.163 \\
\hline & & & & & $(0.3194)$ & $(0.4881)$ & $(0.1841)$ & $(0.2682)$ \\
\hline \multirow[t]{2}{*}{ PROB(BID) } & 0.338 & $-10.322^{* * *}$ & $3.764 * *$ & $-7.820 *$ & -3.328 & $-19.581 * * *$ & -1.328 & -5.682 \\
\hline & $(2.2859)$ & $(3.6034)$ & $(1.7717)$ & $(4.7463)$ & $(3.0512)$ & $(5.8158)$ & $(2.4612)$ & (3.8282) \\
\hline \multicolumn{9}{|c|}{$\underline{\text { Target Characteristics }}$} \\
\hline \multirow[t]{2}{*}{ TARSIZE } & $0.126^{* *}$ & $0.239 * *$ & $0.155^{* * *}$ & -0.131 & $0.124^{*}$ & $0.475^{* * *}$ & 0.097 & -0.093 \\
\hline & $(0.0508)$ & $(0.1007)$ & $(0.0545)$ & $(0.1621)$ & $(0.0722)$ & $(0.1393)$ & $(0.0769)$ & $(0.1098)$ \\
\hline \multirow[t]{2}{*}{ TARROA } & -0.348 & -0.731 & $0.652 *$ & -0.737 & $-0.959 *$ & $-3.242 * * *$ & -0.194 & -0.235 \\
\hline & $(0.3398)$ & $(0.4974)$ & $(0.3660)$ & $(0.7644)$ & $(0.5429)$ & $(1.0116)$ & $(0.5085)$ & $(0.7880)$ \\
\hline \multirow[t]{2}{*}{ TARMB } & -0.027 & 0.007 & -0.003 & -0.044 & $-0.067 * *$ & -0.072 & -0.020 & -0.009 \\
\hline & $(0.0252)$ & $(0.0349)$ & $(0.0281)$ & $(0.0387)$ & $(0.0339)$ & $(0.0567)$ & (0.0385) & $(0.0517)$ \\
\hline \multirow[t]{2}{*}{ TARLEV } & & & & & -0.053 & 0.808 & 0.808* & 0.188 \\
\hline & & & & & $(0.5066)$ & (0.7829) & $(0.4848)$ & $(0.7327)$ \\
\hline \multirow[t]{2}{*}{ TARHERF } & & & & & -0.291 & 0.638 & 0.115 & 0.071 \\
\hline & & & & & $(0.2911)$ & $(0.4460)$ & (0.1659) & $(0.2408)$ \\
\hline \multirow[t]{2}{*}{ RUNUP } & & & & & 0.361 & 0.903 & 0.564 & -0.922 \\
\hline & & & & & $(0.3940)$ & $(0.6179)$ & $(0.4215)$ & $(0.6347)$ \\
\hline
\end{tabular}




\begin{tabular}{|c|c|c|c|c|c|c|c|c|}
\hline \multicolumn{9}{|l|}{ Deal Characteristics } \\
\hline \multirow[t]{2}{*}{ CASH } & 0.171 & 0.035 & 0.173 & 0.000 & 0.208 & 0.209 & 0.191 & -0.335 \\
\hline & $(0.1296)$ & $(0.1805)$ & (0.1278) & (0.2189) & $(0.1769)$ & $(0.3041)$ & $(0.1708)$ & $(0.2531)$ \\
\hline \multirow[t]{2}{*}{ VERTICAL } & -0.166 & -0.105 & 0.000 & 0.000 & -0.240 & -0.574 & 0.000 & 0.000 \\
\hline & $(0.1389)$ & $(0.2138)$ & $(0.0000)$ & $(0.0000)$ & $(0.1922)$ & $(0.4398)$ & $(0.0000)$ & $(0.0000)$ \\
\hline \multirow[t]{2}{*}{ TENDOFFER } & -0.063 & -0.306 & $0.255^{*}$ & -0.098 & 0.079 & -0.358 & 0.270 & -0.264 \\
\hline & $(0.1432)$ & $(0.2124)$ & $(0.1393)$ & $(0.3214)$ & $(0.1872)$ & $(0.2930)$ & $(0.1801)$ & $(0.2762)$ \\
\hline \multirow[t]{2}{*}{ COMPDEAL } & -0.117 & $1.287 * * *$ & 0.161 & $1.196 * * *$ & -0.403 & $1.500^{* * *}$ & 0.397 & $0.883^{* *}$ \\
\hline & $(0.2288)$ & $(0.2215)$ & $(0.2087)$ & $(0.2633)$ & (0.3184) & (0.3708) & $(0.3312)$ & $(0.3967)$ \\
\hline \multirow[t]{2}{*}{ HOSTILEDEAL } & -0.249 & $1.173^{* * *}$ & 0.317 & 0.614 & -0.165 & 0.934 & 0.409 & 0.561 \\
\hline & $(0.3591)$ & $(0.4398)$ & $(0.3825)$ & $(0.4731)$ & $(0.4743)$ & $(0.7226)$ & $(0.5363)$ & $(0.4906)$ \\
\hline \multirow[t]{2}{*}{ Intercept } & $-0.976 * * *$ & $-0.819 *$ & $-0.748 * * *$ & $-2.209 * * *$ & -0.953 & -0.247 & 0.221 & -1.866 \\
\hline & $(0.2387)$ & $(0.4222)$ & $(0.2245)$ & $(0.6788)$ & $(0.7715)$ & $(1.2262)$ & $(0.8481)$ & (1.1990) \\
\hline Pseudo $\mathrm{R}^{2}$ & 0.127 & 0.245 & 0.127 & 0.208 & 0.184 & 0.348 & 0.163 & 0.198 \\
\hline Obs & 726 & 726 & 722 & 722 & 407 & 407 & 409 & 409 \\
\hline
\end{tabular}

\section{Panel B: Probability of Regulatory Action}

\begin{tabular}{|c|c|c|c|c|c|c|c|c|}
\hline & (1) & $(2)$ & (3) & (4) & (5) & (6) & (7) & (8) \\
\hline & \multicolumn{2}{|c|}{ Non-Diversifying } & \multicolumn{2}{|c|}{ Diversifying } & \multicolumn{2}{|c|}{ Non-Diversifying } & \multicolumn{2}{|c|}{ Diversifying } \\
\hline & $1^{\text {st }}$ Stage & $2^{\text {nd }}$ Stage & $1^{\text {st }}$ Stage & $2^{\text {nd }}$ Stage & $1^{\text {st }}$ Stage & $2^{\text {nd }}$ Stage & $1^{\text {st }}$ Stage & $2^{\text {nd }}$ Stage \\
\hline PAC & $0.022 *$ & & -0.007 & & $0.034^{*}$ & & 0.025 & \\
\hline
\end{tabular}



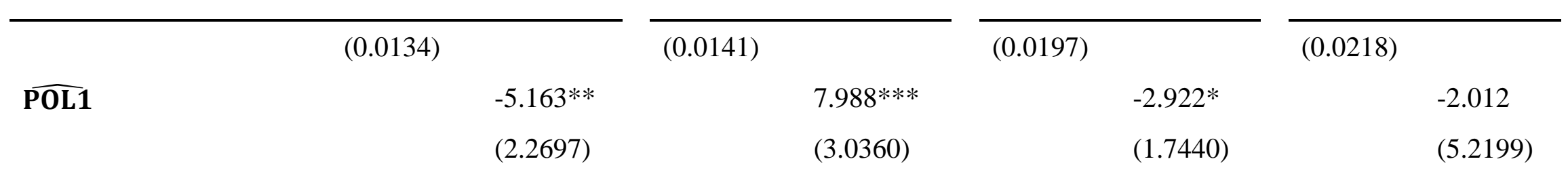

Acquirer Characteristics

\begin{tabular}{|c|c|c|c|c|c|c|c|c|}
\hline \multirow[t]{2}{*}{ RELSIZE } & -0.266 & 0.132 & $-1.099 * * *$ & $2.779 * * *$ & 0.056 & 0.915 & $-1.158 * *$ & -0.008 \\
\hline & $(0.2376)$ & $(0.4306)$ & $(0.2861)$ & $(0.9550)$ & $(0.4335)$ & $(0.6074)$ & $(0.4717)$ & $(2.2055)$ \\
\hline \multirow[t]{2}{*}{ ACQSIZE } & $0.013 * * *$ & $0.022^{* *}$ & $0.005^{* * *}$ & $-0.016 * *$ & $0.012 * * *$ & $0.013^{*}$ & 0.003 & $-0.013 * *$ \\
\hline & $(0.0023)$ & $(0.0103)$ & $(0.0020)$ & $(0.0078)$ & $(0.0033)$ & $(0.0079)$ & $(0.0028)$ & $(0.0067)$ \\
\hline \multirow[t]{2}{*}{ ACQROA } & 0.710 & $3.415^{* *}$ & 0.862 & -0.778 & 0.138 & 2.746 & $-2.518 *$ & 6.452 \\
\hline & $(0.7206)$ & (1.3528) & (0.7899) & (1.8181) & (1.2813) & (1.8593) & $(1.4631)$ & (5.6505) \\
\hline \multirow[t]{2}{*}{ ACQMB } & -0.019 & -0.030 & 0.015 & -0.017 & -0.022 & 0.037 & $0.076 * *$ & 0.121 \\
\hline & $(0.0206)$ & $(0.0319)$ & $(0.0223)$ & $(0.0530)$ & $(0.0298)$ & $(0.0384)$ & $(0.0317)$ & $(0.1616)$ \\
\hline \multirow[t]{2}{*}{ ACQLEV } & 0.278 & $1.290 * *$ & -0.421 & $2.963 * * *$ & 0.208 & $1.387 *$ & -0.974 & 0.693 \\
\hline & $(0.3362)$ & $(0.5111)$ & $(0.3847)$ & $(0.7012)$ & $(0.6208)$ & $(0.7638)$ & $(0.6118)$ & $(2.3256)$ \\
\hline \multirow[t]{2}{*}{ ACQ E-INDEX } & & & & & -0.014 & $0.180 *$ & $-0.128 *$ & -0.160 \\
\hline & & & & & $(0.0672)$ & $(0.1094)$ & $(0.0674)$ & $(0.2729)$ \\
\hline \multirow[t]{2}{*}{ ACQ INDDIR } & & & & & $1.332 * * *$ & 1.041 & $0.983 * *$ & $6.720 * *$ \\
\hline & & & & & $(0.5063)$ & $(1.0246)$ & $(0.4874)$ & (2.7368) \\
\hline \multirow[t]{2}{*}{ AQCBSIZE } & & & & & $0.058 * *$ & 0.046 & -0.003 & 0.005 \\
\hline & & & & & $(0.0283)$ & $(0.0577)$ & $(0.0238)$ & $(0.0694)$ \\
\hline
\end{tabular}




\begin{tabular}{|c|c|c|c|c|c|c|c|c|}
\hline \multirow[t]{2}{*}{ AQCDUAL } & & & & & 0.109 & 0.205 & -0.192 & -0.548 \\
\hline & & & & & $(0.1882)$ & $(0.2953)$ & (0.1989) & $(0.6262)$ \\
\hline \multirow[t]{2}{*}{ AQCINST } & & & & & 0.844 & -0.263 & $1.756^{* *}$ & -1.453 \\
\hline & & & & & $(0.7980)$ & $(1.1346)$ & $(0.7888)$ & (3.6496) \\
\hline \multirow[t]{2}{*}{ AQCHERF } & & & & & $0.531 *$ & 0.268 & 0.179 & -0.167 \\
\hline & & & & & (0.3159) & $(0.5079)$ & $(0.1904)$ & $(0.4425)$ \\
\hline \multicolumn{9}{|c|}{$\underline{\text { Target Characteristics }}$} \\
\hline \multirow[t]{2}{*}{ TARSIZE } & $0.219 * * *$ & $0.706^{* * *}$ & $0.139 * *$ & 0.041 & $0.159 * *$ & $0.383^{* * *}$ & 0.109 & $0.450 *$ \\
\hline & $(0.0548)$ & $(0.1851)$ & $(0.0570)$ & $(0.1571)$ & $(0.0785)$ & $(0.1420)$ & $(0.0839)$ & $(0.2634)$ \\
\hline \multirow[t]{2}{*}{ TARROA } & -0.575 & -0.762 & 0.406 & -0.840 & $-0.924^{*}$ & -0.856 & 0.096 & 1.724 \\
\hline & $(0.3577)$ & $(0.6709)$ & $(0.3805)$ & $(0.9621)$ & $(0.5517)$ & $(1.0495)$ & $(0.5178)$ & $(1.1418)$ \\
\hline \multirow[t]{2}{*}{ TARMB } & -0.015 & -0.021 & -0.021 & -0.025 & -0.022 & -0.060 & -0.038 & $-0.270 * *$ \\
\hline & $(0.0253)$ & $(0.0427)$ & $(0.0278)$ & $(0.0556)$ & $(0.0337)$ & $(0.0474)$ & $(0.0387)$ & $(0.1327)$ \\
\hline \multirow[t]{2}{*}{ TARLEV } & & & & & 0.349 & $1.432 *$ & 0.781 & 1.861 \\
\hline & & & & & $(0.5222)$ & $(0.7500)$ & $(0.5049)$ & $(2.0121)$ \\
\hline \multirow[t]{2}{*}{ TARHERF } & & & & & -0.259 & -0.031 & 0.097 & -0.646 \\
\hline & & & & & $(0.2973)$ & $(0.4821)$ & $(0.1655)$ & $(0.4673)$ \\
\hline \multirow[t]{2}{*}{ RUNUP } & & & & & 0.200 & -0.490 & 0.419 & 0.639 \\
\hline & & & & & $(0.3960)$ & $(0.4762)$ & $(0.4232)$ & (1.1497) \\
\hline
\end{tabular}




\begin{tabular}{|c|c|c|c|c|c|c|c|c|}
\hline \multicolumn{9}{|l|}{$\underline{\text { Deal Characteristics }}$} \\
\hline \multirow[t]{2}{*}{ CASH } & $0.322 * *$ & $0.675 *$ & 0.166 & $-0.641^{* *}$ & $0.369 * *$ & 0.454 & 0.261 & -0.566 \\
\hline & $(0.1259)$ & $(0.3456)$ & $(0.1267)$ & $(0.2887)$ & $(0.1759)$ & $(0.3736)$ & $(0.1719)$ & $(0.5803)$ \\
\hline \multirow[t]{2}{*}{ VERTICAL } & -0.202 & $-0.785^{* *}$ & 0.000 & 0.000 & -0.214 & $-0.760 *$ & 0.000 & 0.000 \\
\hline & $(0.1413)$ & $(0.3965)$ & (.) & (.) & $(0.1897)$ & $(0.4544)$ & (.) & (.) \\
\hline \multirow[t]{2}{*}{ TENDOFFER } & -0.122 & -0.275 & 0.210 & -0.418 & 0.035 & -0.318 & 0.115 & 0.731 \\
\hline & $(0.1465)$ & $(0.3088)$ & $(0.1443)$ & $(0.3696)$ & $(0.1946)$ & $(0.3479)$ & $(0.1770)$ & $(0.5007)$ \\
\hline \multirow[t]{2}{*}{ COMPDEAL } & -0.180 & 0.229 & 0.112 & -0.179 & -0.409 & 0.269 & 0.351 & 0.063 \\
\hline & $(0.3226)$ & $(0.3622)$ & $(0.2725)$ & $(0.4347)$ & $(0.4139)$ & $(0.4679)$ & $(0.4040)$ & $(0.9907)$ \\
\hline \multirow[t]{2}{*}{ HOSTILEDEAL } & 0.014 & -0.159 & $1.277 * * *$ & $-2.525^{* *}$ & 0.330 & 0.165 & $1.160 * *$ & $3.856 *$ \\
\hline & $(0.4875)$ & $(0.5558)$ & $(0.4696)$ & $(1.2321)$ & $(0.6346)$ & $(0.6333)$ & $(0.5552)$ & (2.1739) \\
\hline \multirow[t]{2}{*}{ Intercept } & $-0.656 * * *$ & -1.120 & -0.233 & $-5.159 * * *$ & -1.276 & -1.633 & 0.504 & $-7.583 * *$ \\
\hline & $(0.2242)$ & $(0.8594)$ & $(0.2175)$ & $(1.1677)$ & $(0.8186)$ & $(1.2370)$ & $(0.8784)$ & (3.0243) \\
\hline Pseudo $\mathrm{R}^{2}$ & 0.135 & 0.259 & 0.128 & 0.259 & 0.181 & 0.280 & 0.158 & 0.403 \\
\hline Obs & 699 & 699 & 663 & 663 & 403 & 403 & 404 & 404 \\
\hline
\end{tabular}




\section{Table 5: Takeover Premiums}

This table report results of the following regression: PREM $M_{i, t}=\beta_{0}+\beta_{1}$ POL1 $_{i, t}+\beta_{2}$ RELSIZE $_{i, t}+\beta_{3}$ ACQSIZE $_{i, t}+\beta_{4}$ ACQSALETA $_{i, t}+\beta_{5}$ ACQMB $_{i, t}+$ $\beta_{6}$ ACQLEV $_{i, t}+\beta_{7}$ ACQEINDEX $_{i, t}+\beta_{8}$ ACQBSIZE $_{i, t}+\beta_{9}$ ACQDUAL $_{i, t}+\beta_{10}$ TOEHOLD $_{i, t}+\beta_{11}$ ACQHERF $_{i, t}+\beta_{12}$ TARSIZE $_{i, t}+\beta_{13}$ TARSALETA $_{i, t}+$ $\beta_{14}$ TARMB $_{i, t}+\beta_{15}$ HERF $_{i, t}+\beta_{16}$ RUNUP $_{i, t}+\beta_{17}$ CASH $_{i, t}+\beta_{18}$ VERTICAL $_{i, t}+\beta_{19}$ TENDOFFER $_{i, t}+\beta_{20}$ COMPDEAL $_{i, t}++\beta_{21}$ HOSTDEAL $_{i, t}+$ Industry Dummies + YearDummies $+\varepsilon_{i, t}$, where PREM is one of the three measures of takeover premium: PREMMOEL - the measure based on Moeller (2005), PREMISM - based on Ismail (2011), and PREMBET - based on Betton and Eckbo, (2000). POL1 indicates whether the bidder has a former politician or industry regulator on its board or management team, and RELSIZE is acquirer market capitalization scaled by target market capitalization. Acquirer (target) characteristics include: ACQ(TAR)SIZE - market capitalization, ACQ(TAR)SALE - sales scaled by total assets, ACQ(TAR)MB - market-to-book ratio estimated as the market value of equity divided by book value, $A C Q(T A R) L E V$ - total debt scaled by total assets, and ACQ(TAR)HERF - the Herfindahl index of industry concertation based on sales. Governance attributes of the acquirer include: ACQ E-INDEX, ACQBSIZE, and ACQDUAL- entrenchment index from Bebchuk et al. (2009), board size, and CEO/Chairman duality, institutional ownership. TOEHOLD is the percentage of the target's outstanding shares the acquirer owns prior to the announcement of the transaction. RUNUP is target share price runup from $t-230$ to $t-11$ days prior to the bid announcement. Deal characteristics include: CASH, VERTICAL, TENDOFFER, COMPDEAL, and HOSTILEDEAL - dummy variables that take value one if the transaction includes a cash component, if the acquisition is vertical according to Acemoglu et al. (2009), if it is a tender-offer, if there is more than one bidder, and if it is hostile according to SDC,

respectively. Columns (1), (3), and (5) are estimated for non-diversifying deals. White’s heteroscedasticity-robust standard errors are shown in parentheses. *, **, and $* * *$ indicate significance at the $10 \%, 5 \%$, and $1 \%$ levels, respectively.

\begin{tabular}{|c|c|c|c|c|c|}
\hline (1) & (2) & (3) & (4) & (5) & (6) \\
\hline \multicolumn{2}{|c|}{ PREMMOEL } & \multicolumn{2}{|c|}{ PREMISM } & \multicolumn{2}{|c|}{ PREMBET } \\
\hline Non-Diversifying & Diversifying & Non-Diversifying & Diversifying & Non-Diversifying & Diversifying \\
\hline $0.073^{*}$ & 0.026 & $0.085 * *$ & 0.037 & $0.067 *$ & 0.014 \\
\hline$(0.0407)$ & $(0.0405)$ & $(0.0401)$ & $(0.0408)$ & $(0.0392)$ & $(0.0390)$ \\
\hline$-0.240 * *$ & $-0.255^{* *}$ & $-0.241 * *$ & $-0.242 *$ & $-0.213 * *$ & $-0.257 * *$ \\
\hline$(0.0940)$ & $(0.1279)$ & $(0.0936)$ & $(0.1262)$ & $(0.0931)$ & $(0.1186)$ \\
\hline-0.000 & -0.001 & -0.000 & -0.001 & -0.000 & -0.001 \\
\hline$(0.0008)$ & $(0.0011)$ & $(0.0007)$ & $(0.0011)$ & $(0.0007)$ & $(0.0011)$ \\
\hline
\end{tabular}




\begin{tabular}{|c|c|c|c|c|c|c|}
\hline ACQSALETA & $\begin{array}{l}-0.064 \\
(0.0737)\end{array}$ & $\begin{array}{l}-0.130 \\
(0.1025)\end{array}$ & $\begin{array}{l}-0.035 \\
(0.0733)\end{array}$ & $\begin{array}{l}-0.139 \\
(0.1049)\end{array}$ & $\begin{array}{l}-0.051 \\
(0.0575)\end{array}$ & $\begin{array}{l}-0.042 \\
(0.0633)\end{array}$ \\
\hline ACQMB & $\begin{array}{l}-0.007 \\
(0.0072)\end{array}$ & $\begin{array}{l}0.021 \\
(0.0151)\end{array}$ & $\begin{array}{l}-0.005 \\
(0.0070)\end{array}$ & $\begin{array}{l}0.021 \\
(0.0135)\end{array}$ & $\begin{array}{l}-0.004 \\
(0.0069)\end{array}$ & $\begin{array}{l}0.017 \\
(0.0133)\end{array}$ \\
\hline ACQLEV & $\begin{array}{l}-0.053 \\
(0.1602)\end{array}$ & $\begin{array}{l}0.184 \\
(0.2810)\end{array}$ & $\begin{array}{l}0.007 \\
(0.1546)\end{array}$ & $\begin{array}{l}0.212 \\
(0.2887)\end{array}$ & $\begin{array}{l}-0.021 \\
(0.1294)\end{array}$ & $\begin{array}{l}0.162 \\
(0.2810)\end{array}$ \\
\hline ACQ E-INDEX & $\begin{array}{l}0.002 \\
(0.0176)\end{array}$ & $\begin{array}{l}0.001 \\
(0.0205)\end{array}$ & $\begin{array}{l}0.000 \\
(0.0179)\end{array}$ & $\begin{array}{l}0.003 \\
(0.0206)\end{array}$ & $\begin{array}{l}0.005 \\
(0.0176)\end{array}$ & $\begin{array}{l}0.002 \\
(0.0203)\end{array}$ \\
\hline ACQBSIZE & $\begin{array}{l}-0.007 \\
(0.0101)\end{array}$ & $\begin{array}{l}-0.008 \\
(0.0083)\end{array}$ & $\begin{array}{l}-0.005 \\
(0.0098)\end{array}$ & $\begin{array}{l}-0.010 \\
(0.0083)\end{array}$ & $\begin{array}{l}-0.008 \\
(0.0095)\end{array}$ & $\begin{array}{l}-0.008 \\
(0.0077)\end{array}$ \\
\hline ACQDUAL & $\begin{array}{l}-0.035 \\
(0.0462)\end{array}$ & $\begin{array}{l}0.050 \\
(0.0619)\end{array}$ & $\begin{array}{l}-0.030 \\
(0.0453)\end{array}$ & $\begin{array}{l}0.033 \\
(0.0634)\end{array}$ & $\begin{array}{l}-0.031 \\
(0.0435)\end{array}$ & $\begin{array}{l}0.037 \\
(0.0602)\end{array}$ \\
\hline TOEHOLD & $\begin{array}{l}0.008 \\
(0.0390)\end{array}$ & $\begin{array}{l}0.058 * \\
(0.0311)\end{array}$ & $\begin{array}{l}0.009 \\
(0.0387)\end{array}$ & $\begin{array}{l}0.059 * \\
(0.0316)\end{array}$ & $\begin{array}{l}0.026 \\
(0.0377)\end{array}$ & $\begin{array}{l}0.063 * * \\
(0.0306)\end{array}$ \\
\hline ACQHERF & $\begin{array}{l}-0.220 \\
(0.1389)\end{array}$ & $\begin{array}{l}-0.106 \\
(0.1146)\end{array}$ & $\begin{array}{l}-0.249 * \\
(0.1375)\end{array}$ & $\begin{array}{l}-0.106 \\
(0.1202)\end{array}$ & $\begin{array}{l}-0.228^{*} \\
(0.1378)\end{array}$ & $\begin{array}{l}-0.142 \\
(0.1157)\end{array}$ \\
\hline Target Character & & & & & & \\
\hline TARSIZE & $\begin{array}{l}-0.012 \\
(0.0179)\end{array}$ & $\begin{array}{l}-0.024 \\
(0.0295)\end{array}$ & $\begin{array}{l}-0.013 \\
(0.0180)\end{array}$ & $\begin{array}{l}-0.017 \\
(0.0279)\end{array}$ & $\begin{array}{l}-0.009 \\
(0.0180)\end{array}$ & $\begin{array}{l}-0.027 \\
(0.0277)\end{array}$ \\
\hline TARSALETA & $\begin{array}{l}0.079 \\
(0.0523)\end{array}$ & $\begin{array}{l}-0.062 \\
(0.0564)\end{array}$ & $\begin{array}{l}0.078 \\
(0.0509)\end{array}$ & $\begin{array}{l}-0.057 \\
(0.0526)\end{array}$ & $\begin{array}{l}0.064 \\
(0.0522)\end{array}$ & $\begin{array}{l}-0.084 \\
(0.0522)\end{array}$ \\
\hline TARMB & -0.013 & 0.002 & -0.010 & -0.002 & -0.010 & 0.000 \\
\hline
\end{tabular}




\begin{tabular}{|c|c|c|c|c|c|c|}
\hline & $(0.0082)$ & $(0.0152)$ & $(0.0081)$ & $(0.0143)$ & $(0.0078)$ & $(0.0147)$ \\
\hline \multirow[t]{2}{*}{ TARLEV } & 0.050 & 0.081 & 0.069 & 0.028 & 0.056 & 0.332 \\
\hline & $(0.1387)$ & $(0.1747)$ & $(0.1419)$ & $(0.1640)$ & $(0.0906)$ & $(0.2167)$ \\
\hline \multirow[t]{2}{*}{ TARHERF } & 0.199 & 0.020 & $0.224^{*}$ & 0.015 & 0.208 & 0.020 \\
\hline & $(0.1331)$ & $(0.0513)$ & $(0.1320)$ & $(0.0502)$ & $(0.1311)$ & $(0.0484)$ \\
\hline \multirow[t]{2}{*}{ RUNUP } & $-0.266 * * *$ & $-0.322 * *$ & $-0.317 * * *$ & $-0.334 * *$ & $-0.321 * * *$ & $-0.263 *$ \\
\hline & $(0.0996)$ & $(0.1609)$ & $(0.0970)$ & (0.1619) & $(0.0960)$ & $(0.1470)$ \\
\hline \multicolumn{7}{|c|}{ Deal Characteristics } \\
\hline \multirow[t]{2}{*}{ CASH } & -0.024 & 0.035 & -0.026 & 0.051 & -0.019 & 0.051 \\
\hline & $(0.0456)$ & $(0.0468)$ & $(0.0456)$ & $(0.0443)$ & $(0.0444)$ & $(0.0438)$ \\
\hline \multirow[t]{2}{*}{ VERTICAL } & $0.109 * *$ & 0.000 & $0.090^{*}$ & 0.000 & $0.106 * *$ & 0.000 \\
\hline & $(0.0512)$ & $(0.0000)$ & $(0.0502)$ & $(0.0000)$ & $(0.0525)$ & $(0.0000)$ \\
\hline \multirow[t]{2}{*}{ TENDOFFER } & 0.057 & -0.040 & 0.064 & -0.048 & $0.077^{*}$ & -0.021 \\
\hline & $(0.0421)$ & $(0.0517)$ & $(0.0417)$ & $(0.0514)$ & $(0.0431)$ & $(0.0501)$ \\
\hline \multirow[t]{2}{*}{ COMPDEAL } & 0.071 & 0.027 & 0.087 & 0.043 & 0.043 & 0.036 \\
\hline & $(0.0717)$ & $(0.0886)$ & $(0.0720)$ & $(0.0979)$ & $(0.0718)$ & $(0.0921)$ \\
\hline \multirow[t]{2}{*}{ HOSTILEDEAL } & $-0.145 *$ & 0.156 & -0.094 & 0.119 & $-0.224^{* *}$ & 0.187 \\
\hline & $(0.0878)$ & $(0.1423)$ & $(0.0942)$ & $(0.1448)$ & $(0.0965)$ & $(0.1366)$ \\
\hline \multirow[t]{2}{*}{ Intercept } & 0.380 & 0.163 & 0.307 & 0.216 & 0.395 & 0.009 \\
\hline & $(0.3700)$ & $(0.3843)$ & $(0.3461)$ & $(0.3931)$ & $(0.3461)$ & $(0.3613)$ \\
\hline $\mathrm{R}^{2}$ & 0.388 & 0.294 & 0.393 & 0.307 & 0.397 & 0.294 \\
\hline $\mathrm{N}$ & 425 & 456 & 425 & 456 & 430 & 462 \\
\hline
\end{tabular}




\section{Table 6: Cumulative Abnormal Return around Announcement of Deal}

Panels A through D compare the difference in the average cumulative abnormal returns of politically connected and non-connected acquirers around the announcement of a merger bid. Panel A examines investor response around all bid announcements, Panel B is centered around announcements of deals between direct competitors (horizontal acquisitions), Panel C focuses on the announcement of deals between buyers and suppliers (vertical acquisitions), Panel D

examines the announcement of the non-diversifying acquisitions. PC indicates politically connected firms, and NPC refers to non-connected firms. Firms which are politically connected according to POL1 have at least one member of the board of directors or a manager who is a former politician or regulator. POL2 defines politically connected firms as those firms which have a former politician, regulator on their board or management team, or former senior member of the military. POL3 defines politically connected firms as those firms which have a former politician, regulator, senior military officer, or lawyer on the board or management team. Panel E reports the multivariate tests of the relation between cumulative abnormal returns and political connections: $C A R=\beta_{0}+\beta_{1} P O L_{i, t}+$ $\beta_{2}$ ACQSIZE $_{i, t}+\beta_{3}$ ACQMB $_{i, t}+\beta_{6}$ TARSIZE $_{i, t}+\beta_{7}$ TARROA $_{i, t}+\beta_{8}$ TARMB $_{i, t}+\beta_{9}$ TRANSVAL $_{i, t}+\beta_{10}$ CASH $_{i, t}+\beta_{11} V_{E R T I C A L_{i, t}}+$

$\beta_{12}$ HORIZONTAL $L_{i, t}+\beta_{13}$ TENDOFFER $R_{i, t}+\beta_{14}$ COMPDEAL $L_{i, t}++\beta_{15}$ HOSTDEAL $L_{i, t}+$ Industry Dummies + YearDummies $+\varepsilon_{i, t}$. Acquirer (target) characteristics include: ACQ(TAR)SIZE - market capitalization, TARROA - target return on assets estimated as is the ratio of operating earnings to firms' total assets, $A C Q(T A R) M B$ - market-to-book ratio estimated as the market value of equity divided by book value. Deal characteristics include: TRANSVAL, CASH, VERTICAL, HORIZONTAL, TENDOFFER, COMPDEAL, and HOSTILEDEAL - natural logarithm of transaction value, dummy variables that take value one if the transaction includes a cash component, if the acquisition is vertical according to Acemoglu et al. (2009), if it is horizontal, if it is a tender-offer, if there is more than one bidder, and if it is hostile according to SDC, respectively. White's heteroscedasticity-robust standard errors are shown in parentheses. *, **, and *** indicate significance at the $10 \%, 5 \%$, and $1 \%$

\section{Panel A: All deals}

\begin{tabular}{|c|c|c|c|c|c|c|c|c|c|c|c|c|}
\hline & \multicolumn{4}{|c|}{ POL1 } & \multicolumn{4}{|c|}{ POL2 } & \multicolumn{4}{|c|}{ POL3 } \\
\hline & PC & NPC & Difference & P-value & PC & NPC & Difference & P-value & PC & NPC & Difference & P-value \\
\hline$(-1,0)$ & $-0.77 \%$ & $-1.39 \%$ & $0.62 \% * *$ & $(0.027)$ & $-0.71 \%$ & $-1.43 \%$ & $0.72 \% * *$ & $(0.012)$ & $-1.14 \%$ & $-1.22 \%$ & $0.08 \%$ & $(0.405)$ \\
\hline$(-1,+1)$ & $-0.95 \%$ & $-1.88 \%$ & $0.93 \% * *$ & $(0.010)$ & $-0.88 \%$ & $-1.94 \%$ & $1.05 \% * * *$ & $(0.004)$ & $-1.27 \%$ & $-1.91 \%$ & $0.64 \% *$ & $(0.061)$ \\
\hline$(-2,+2)$ & $-1.10 \%$ & $-1.99 \%$ & $0.89 \% * *$ & $(0.019)$ & $-1.04 \%$ & $-2.04 \%$ & $1.00 \% * * *$ & $(0.010)$ & $-1.43 \%$ & $-1.98 \%$ & $0.55 \%$ & $(0.112)$ \\
\hline$(-3,+3)$ & $-1.23 \%$ & $-2.16 \%$ & $0.92 \% * *$ & $(0.024)$ & $-1.14 \%$ & $-2.23 \%$ & $1.09 \% * * *$ & $(0.010)$ & $-1.56 \%$ & $-2.17 \%$ & $0.60 \%$ & $(0.113)$ \\
\hline$(-5,+5)$ & $-1.54 \%$ & $-1.79 \%$ & $0.25 \%$ & $(0.321)$ & $-1.46 \%$ & $-1.84 \%$ & $0.38 \%$ & $(0.238)$ & $-1.64 \%$ & $-1.77 \%$ & $0.13 \%$ & $(0.410)$ \\
\hline
\end{tabular}




\begin{tabular}{|c|c|c|c|c|c|c|c|c|c|c|c|c|}
\hline \multicolumn{13}{|c|}{ Panel B: Horizontal Acquisitions } \\
\hline & \multicolumn{4}{|c|}{ POL1 } & \multicolumn{4}{|c|}{ POL2 } & \multicolumn{4}{|c|}{ POL3 } \\
\hline & PC & NPC & Difference & P-value & PC & NPC & Difference & P-value & PC & NPC & Difference & P-value \\
\hline$(-1,0)$ & $-0.85 \%$ & $-1.46 \%$ & $0.61 \%$ & $(0.13)$ & $-0.82 \%$ & $-1.48 \%$ & $0.66 \%$ & $(0.109)$ & $-1.37 \%$ & $-1.15 \%$ & $-0.22 \%$ & $(0.338)$ \\
\hline$(-1,+1)$ & $-1.17 \%$ & $-2.07 \%$ & $0.90 \% *$ & $(0.095)$ & $-1.18 \%$ & $-2.08 \%$ & $0.90 \% *$ & $(0.098)$ & $-1.53 \%$ & $-2.04 \%$ & $0.51 \%$ & $(0.229)$ \\
\hline$(-2,+2)$ & $-1.40 \%$ & $-2.10 \%$ & $0.70 \%$ & $(0.177)$ & $-1.36 \%$ & $-2.13 \%$ & $0.76 \%$ & $(0.156)$ & $-1.78 \%$ & $-1.97 \%$ & $0.19 \%$ & $(0.402)$ \\
\hline$(-3,+3)$ & $-1.28 \%$ & $-2.26 \%$ & $0.98 \%$ & $(0.113)$ & $-1.24 \%$ & $-2.29 \%$ & $1.04 \% *$ & (0.098) & $-1.77 \%$ & $-2.12 \%$ & $0.36 \%$ & (0.329) \\
\hline$(-5,+5)$ & $-2.29 \%$ & $-1.83 \%$ & $-0.45 \%$ & $(0.303)$ & $-2.26 \%$ & $-1.85 \%$ & $-0.41 \%$ & (0.319) & $-2.32 \%$ & $-1.64 \%$ & $-0.68 \%$ & $(0.215)$ \\
\hline
\end{tabular}

\begin{tabular}{|c|c|c|c|c|c|c|c|c|c|c|c|c|}
\hline \multicolumn{13}{|c|}{ Panel C: Vertical Acquisitions } \\
\hline & \multicolumn{4}{|c|}{ POL1 } & \multicolumn{4}{|c|}{ POL2 } & \multicolumn{4}{|c|}{ POL3 } \\
\hline & PC & NPC & Difference & P-value & PC & NPC & Difference & P-value & PC & NPC & Difference & P-value \\
\hline$(-1,0)$ & $-1.14 \%$ & $-1.61 \%$ & $0.47 \%$ & $(0.314)$ & $-1.02 \%$ & $-1.71 \%$ & $0.69 \%$ & $(0.240)$ & $-0.74 \%$ & $-2.31 \%$ & $1.57 \% *$ & $(0.069)$ \\
\hline$(-1,+1)$ & $-1.12 \%$ & $-1.79 \%$ & $0.67 \%$ & $(0.300)$ & $-1.04 \%$ & $-1.86 \%$ & $0.82 \%$ & $(0.258)$ & $-1.04 \%$ & $-2.16 \%$ & $1.11 \%$ & $(0.192)$ \\
\hline$(-2,+2)$ & $-1.37 \%$ & $-1.86 \%$ & $0.49 \%$ & $(0.356)$ & $-1.32 \%$ & $-1.92 \%$ & $0.60 \%$ & $(0.117)$ & $-1.44 \%$ & $-1.99 \%$ & $0.55 \%$ & $(0.345)$ \\
\hline$(-3,+3)$ & $-1.53 \%$ & $-1.98 \%$ & $0.45 \%$ & $(0.387)$ & $-1.44 \%$ & $-2.06 \%$ & $0.62 \%$ & $(0.347)$ & $-1.47 \%$ & $-2.25 \%$ & $0.79 \%$ & $(0.321)$ \\
\hline$(-5,+5)$ & $-0.59 \%$ & $-1.13 \%$ & $0.54 \%$ & $(0.382)$ & $-0.55 \%$ & $-1.17 \%$ & $0.62 \%$ & $(0.365)$ & $-0.91 \%$ & $-0.95 \%$ & $0.04 \%$ & $(0.492)$ \\
\hline
\end{tabular}




\begin{tabular}{|c|c|c|c|c|c|c|c|c|c|c|c|c|}
\hline & & & OL1 & & & & OL2 & & & & OL3 & \\
\hline & PC & NPC & Difference & P-value & PC & NPC & Difference & P-value & PC & NPC & Difference & P-value \\
\hline$(-1,0)$ & $-0.91 \%$ & $-1.49 \%$ & $0.57 \%$ & $(0.112)$ & $-0.87 \%$ & $-1.52 \%$ & $0.65 \% *$ & $(0.080)$ & $-1.24 \%$ & $-1.36 \%$ & $0.12 \%$ & (0.395) \\
\hline$(-1,+1)$ & $-1.16 \%$ & $-2.02 \%$ & $0.86 \% *$ & $(0.081)$ & $-1.15 \%$ & $-2.04 \%$ & $0.89 \% *$ & $(0.071)$ & $-1.43 \%$ & $-2.06 \%$ & $0.63 \%$ & $(0.148)$ \\
\hline$(-2,+2)$ & $-1.40 \%$ & $-2.06 \%$ & $0.66 \%$ & $(0.157)$ & $-1.35 \%$ & $-2.09 \%$ & $0.74 \%$ & (0.130) & $-1.71 \%$ & $-1.97 \%$ & $0.26 \%$ & $(0.346)$ \\
\hline$(-3,+3)$ & $-1.34 \%$ & $-2.21 \%$ & $0.87 \%$ & $(0.111)$ & $-1.29 \%$ & $-2.25 \%$ & $0.96 \% *$ & $(0.089)$ & $-1.70 \%$ & $-2.15 \%$ & $0.44 \%$ & $(0.271)$ \\
\hline$(-5,+5)$ & $-1.91 \%$ & $-1.70 \%$ & $-0.21 \%$ & (0.397) & $-1.87 \%$ & $-1.72 \%$ & $-0.14 \%$ & $(0.427)$ & $-2.02 \%$ & $-1.51 \%$ & $-0.50 \%$ & $(0.262)$ \\
\hline
\end{tabular}

\begin{tabular}{|c|c|c|c|c|c|c|c|c|c|}
\hline \multicolumn{10}{|c|}{ Panel E: Multivariate Analysis } \\
\hline & $(1)$ & (2) & (3) & (4) & (5) & (6) & (7) & (8) & (9) \\
\hline & \multicolumn{3}{|c|}{$(-1,+1)$} & \multicolumn{3}{|c|}{$(-2,+2)$} & \multicolumn{3}{|c|}{$(-3,+3)$} \\
\hline \multirow[t]{2}{*}{ POL1 } & 0.006 & & & $0.008^{*}$ & & & $0.009 *$ & & \\
\hline & $(0.0046)$ & & & $(0.0049)$ & & & $(0.0054)$ & & \\
\hline \multirow[t]{2}{*}{ POL2 } & & $0.008 *$ & & & $0.010 * *$ & & & $0.011^{* *}$ & \\
\hline & & $(0.0046)$ & & & $(0.0049)$ & & & $(0.0054)$ & \\
\hline \multirow[t]{2}{*}{ POL3 } & & & 0.002 & & & 0.003 & & & 0.003 \\
\hline & & & $(0.0043)$ & & & $(0.0047)$ & & & $(0.0053)$ \\
\hline \multirow[t]{2}{*}{ ACQSIZE } & $0.0003^{* * *}$ & $0.0003^{* * *}$ & $0.0003^{* * *}$ & $0.0004^{* * *}$ & $0.0004^{* * *}$ & $0.0004^{* * *}$ & $0.0003^{* * *}$ & $0.0003^{* * *}$ & $0.000 * * *$ \\
\hline & $(0.0001)$ & $(0.0001)$ & $(0.0001)$ & $(0.0001)$ & $(0.0001)$ & $(0.0001)$ & $(0.0001)$ & $(0.0001)$ & $(0.0001)$ \\
\hline \multirow[t]{2}{*}{ ACQMB } & -0.000 & -0.000 & -0.000 & 0.0001 & 0.0001 & 0.0001 & 0.0004 & 0.0004 & 0.0004 \\
\hline & $(0.0011)$ & $(0.0011)$ & $(0.0011)$ & $(0.0012)$ & $(0.0012)$ & $(0.0012)$ & $(0.0013)$ & $(0.0013)$ & $(0.0013)$ \\
\hline TARSIZE & 0.003 & 0.003 & 0.003 & 0.003 & 0.003 & 0.003 & 0.004 & 0.004 & 0.004 \\
\hline
\end{tabular}




\begin{tabular}{|c|c|c|c|c|c|c|c|c|c|}
\hline & $(0.0032)$ & $(0.0032)$ & $(0.0032)$ & $(0.0036)$ & $(0.0036)$ & $(0.0036)$ & $(0.0037)$ & $(0.0037)$ & $(0.0037)$ \\
\hline \multirow[t]{2}{*}{ TARMB } & -0.001 & -0.001 & -0.001 & -0.000 & -0.000 & -0.000 & 0.000 & 0.000 & 0.000 \\
\hline & $(0.0012)$ & $(0.0012)$ & $(0.0012)$ & $(0.0013)$ & $(0.0013)$ & $(0.0013)$ & $(0.0014)$ & $(0.0014)$ & $(0.0014)$ \\
\hline \multirow[t]{2}{*}{ TARROA } & 0.006 & 0.006 & 0.005 & 0.003 & 0.003 & 0.002 & 0.020 & 0.021 & 0.020 \\
\hline & $(0.0188)$ & $(0.0188)$ & $(0.0188)$ & $(0.0204)$ & (0.0203) & (0.0203) & $(0.0219)$ & $(0.0218)$ & $(0.0218)$ \\
\hline \multirow[t]{2}{*}{ TRANSVAL } & $-0.013 * * *$ & $-0.013 * * *$ & $-0.012 * * *$ & $-0.014 * * *$ & $-0.014 * * *$ & $-0.014 * * *$ & $-0.014 * * *$ & $-0.014 * * *$ & $-0.014 * * *$ \\
\hline & $(0.0024)$ & $(0.0024)$ & $(0.0024)$ & $(0.0028)$ & $(0.0028)$ & $(0.0028)$ & $(0.0029)$ & $(0.0028)$ & $(0.0028)$ \\
\hline \multirow[t]{2}{*}{ CASH } & $0.022 * * *$ & $0.022 * * *$ & $0.023 * * *$ & $0.019 * * *$ & $0.019 * * *$ & $0.020 * * *$ & $0.025 * * *$ & $0.025 * * *$ & $0.026 * * *$ \\
\hline & $(0.0052)$ & $(0.0051)$ & $(0.0052)$ & $(0.0055)$ & $(0.0055)$ & $(0.0055)$ & $(0.0061)$ & $(0.0061)$ & $(0.0061)$ \\
\hline \multirow[t]{2}{*}{ VERTICAL } & -0.009 & -0.009 & -0.009 & -0.006 & -0.006 & -0.007 & -0.007 & -0.007 & -0.007 \\
\hline & $(0.0079)$ & $(0.0078)$ & $(0.0078)$ & $(0.0084)$ & $(0.0083)$ & $(0.0083)$ & $(0.0098)$ & $(0.0098)$ & $(0.0098)$ \\
\hline \multirow[t]{2}{*}{ HORIZONTAL } & 0.002 & 0.002 & 0.002 & 0.005 & 0.005 & 0.005 & 0.008 & 0.008 & 0.008 \\
\hline & $(0.0049)$ & $(0.0049)$ & $(0.0049)$ & $(0.0054)$ & $(0.0054)$ & $(0.0054)$ & $(0.0058)$ & $(0.0058)$ & $(0.0058)$ \\
\hline \multirow[t]{2}{*}{ TENDOFFER } & 0.009 & 0.009 & 0.009 & $0.013 *$ & $0.013 *$ & $0.012 *$ & $0.013^{*}$ & $0.013^{*}$ & $0.012 *$ \\
\hline & $(0.0059)$ & $(0.0059)$ & $(0.0059)$ & $(0.0067)$ & $(0.0067)$ & $(0.0067)$ & $(0.0074)$ & $(0.0074)$ & $(0.0074)$ \\
\hline \multirow[t]{2}{*}{ COMPDEAL } & -0.006 & -0.006 & -0.006 & -0.004 & -0.004 & -0.005 & -0.005 & -0.005 & -0.006 \\
\hline & $(0.0134)$ & $(0.0134)$ & $(0.0134)$ & (0.0159) & $(0.0159)$ & (0.0159) & $(0.0159)$ & $(0.0159)$ & $(0.0159)$ \\
\hline \multirow[t]{2}{*}{ HOSTILEDEAL } & -0.002 & -0.002 & -0.001 & -0.010 & -0.010 & -0.009 & -0.029 & -0.029 & -0.028 \\
\hline & $(0.0167)$ & $(0.0167)$ & $(0.0166)$ & $(0.0204)$ & $(0.0205)$ & $(0.0201)$ & $(0.0237)$ & $(0.0237)$ & $(0.0235)$ \\
\hline \multirow[t]{2}{*}{ Intercept } & $0.040 * * *$ & $0.039 * * *$ & $0.040 * * *$ & $0.037 * *$ & $0.037 * *$ & $0.037 * *$ & $0.030 *$ & $0.030^{*}$ & $0.031^{*}$ \\
\hline & $(0.0142)$ & $(0.0142)$ & $(0.0145)$ & $(0.0167)$ & $(0.0167)$ & $(0.0169)$ & $(0.0175)$ & $(0.0175)$ & $(0.0178)$ \\
\hline $\operatorname{adj} . R^{2}$ & 0.149 & 0.150 & 0.148 & 0.156 & 0.157 & 0.155 & 0.155 & 0.156 & 0.153 \\
\hline Obs & 1428 & 1428 & 1428 & 1428 & 1428 & 1428 & 1428 & 1428 & 1428 \\
\hline
\end{tabular}




\section{Table 7: Share Returns Surrounding Regulatory Actions}

This table examines the relation between equity returns around select announcements during the merger review process and political connections. Panel A examines investor response surrounding the early termination date of the merger review process, and Panel B reports return analysis for the period surrounding the announcement of litigation resolution. $P C$ indicates politically connected firms while $N P C$ refers to non-connected firms. Firms which are politically connected according to POL1 have at least one member of the board of directors or a manager who is a former politician or regulator. POL2 defines politically connected firms as those firms which have a former politician, regulator on their board or management team, or former senior member of the military. POL3 defines politically connected firms as those firms which have a former politician, regulator, senior military officer, or lawyer on the board or management team Panel C reports the results of the following multivariate regressions: CAR $=\beta_{0}+\beta_{1}$ POL $_{i, t}+\beta_{2}$ ACQSIZE $_{i, t}+\beta_{3}$ TARSIZE $_{i, t}+\beta_{4}$ TARROA $_{i, t}+$ $\beta_{5}$ TRANSVAL $_{i, t}+\beta_{6} R E G_{i, t}+\beta_{7}$ STATE $_{i, t}+\beta_{8}$ HORIZONTAL $_{i, t}++\varepsilon_{i, t}$. ACQ(TAR)SIZE is acquirer (target) market capitalization, TARROA - target return on assets estimated as is the ratio of operating earnings to firms' total assets. Deal characteristics include: TRANSVAL, REG, STATE, and HORIZONTAL - the natural logarithm of transaction value, dummy variables that take value one if acquirers are regulated firms (primary SIC code between 4000-4999 and 60006999), if the target and acquirer are headquartered in the same state, and if it is horizontal merger, respectively. White’s heteroscedasticity-robust standard errors are shown in parentheses. $*$, **, and $* * *$ indicate significance at the $10 \%, 5 \%$, and $1 \%$

\section{Panel A: Return Analysis Surrounding the Early Termination Date}

\begin{tabular}{llllllllllllll} 
& \multicolumn{1}{c}{ POL1 } & \multicolumn{1}{c}{ POL2 } & \multicolumn{1}{c}{ POL3 } \\
\cline { 2 - 13 } 3 Day & PC & NPC & Difference & P-value & PC & NPC & Difference & P-value & PC & NPC & Difference & P-value \\
\cline { 2 - 12 } & $-0.49 \%$ & $0.70 \%$ & $-1.18 \% * *$ & $(0.049)$ & $-0.49 \%$ & $0.70 \%$ & $-1.18 \% * *$ & $(0.049)$ & $-0.34 \%$ & $0.61 \%$ & $-0.95 \%$ & $(0.101)$ \\
7 Day & $-0.20 \%$ & $1.41 \%$ & $-1.61 \% *$ & $(0.071)$ & $-0.20 \%$ & $1.41 \%$ & $-1.61 \% *$ & $(0.071)$ & $-0.07 \%$ & $1.45 \%$ & $-1.52 \%$ & $(0.106)$ \\
11 Day & $-1.18 \%$ & $0.85 \%$ & $-2.03 \%$ & $(0.117)$ & $-1.18 \%$ & $0.85 \%$ & $-2.03 \%$ & $(0.117)$ & $-1.08 \%$ & $1.03 \%$ & $-2.11 \%$ & $(0.108)$ \\
15 Day & $-0.95 \%$ & $1.61 \%$ & $-2.56 \% * *$ & $(0.046)$ & $-0.95 \%$ & $1.61 \%$ & $-2.56 \%$ & $(0.046)$ & $-0.70 \%$ & $1.57 \%$ & $-2.27 \% *$ & $(0.086)$ \\
\hline
\end{tabular}

\section{Panel B: Return Analysis Surrounding the Resolution of Litigation}

\begin{tabular}{llllllllllllll} 
& \multicolumn{1}{c}{ POL1 } & \multicolumn{1}{c}{ POL2 } & \multicolumn{3}{c}{ POL3 } \\
\cline { 2 - 14 } 3 Day & PC & NPC & Difference & P-value & PC & NPC & Difference & P-value & PC & NPC & Difference & P-value \\
\cline { 2 - 15 } & $-0.24 \%$ & $-0.09 \%$ & $-0.15 \%$ & 0.351 & $-0.30 \%$ & $-0.04 \%$ & $-0.26 \%$ & 0.254 & $-0.22 \%$ & $-0.06 \%$ & $-0.16 \%$ & 0.340 \\
\hline Day & $-0.21 \%$ & $0.44 \%$ & $-0.66 \%$ & 0.126 & $-0.22 \%$ & $0.46 \%$ & $-0.68 \%$ & 0.114 & $-0.17 \%$ & $0.60 \%$ & $-0.77 \%$ & 0.085 \\
\hline
\end{tabular}




\begin{tabular}{lllllllllllll}
\hline 11 Day & $-0.68 \%$ & $0.75 \%$ & $-1.43 \%$ & 0.027 & $-0.62 \%$ & $0.74 \%$ & $-1.36 \%$ & 0.032 & $-0.43 \%$ & $0.91 \%$ & $-1.34 \%$ & 0.032 \\
15 Day & $-1.24 \%$ & $0.44 \%$ & $-1.68 \%$ & 0.022 & $-1.22 \%$ & $0.47 \%$ & $-1.69 \%$ & 0.020 & $-1.07 \%$ & $0.78 \%$ & $-1.85 \%$ & 0.012 \\
\hline
\end{tabular}

\begin{tabular}{|c|c|c|c|c|}
\hline \multicolumn{5}{|c|}{ Panel C: Multivariate Analysis } \\
\hline & (1) & (2) & (3) & (4) \\
\hline & $(-1,+1)$ & $(-3,+3)$ & $(-5,+5)$ & $(-7,+7)$ \\
\hline \multirow[t]{2}{*}{ POL1 } & $-0.014 * *$ & $-0.020 *$ & -0.029 & $-0.031 *$ \\
\hline & $(0.0069)$ & $(0.0122)$ & $(0.0190)$ & $(0.0168)$ \\
\hline \multirow[t]{2}{*}{ ACQSIZE } & 0.00001 & 0.00005 & 0.0002 & 0.0002 \\
\hline & $(0.0001)$ & $(0.0002)$ & $(0.0002)$ & $(0.0002)$ \\
\hline \multirow[t]{2}{*}{ TARSIZE } & $0.003^{* * *}$ & 0.002 & $0.006 * *$ & $0.008 * * *$ \\
\hline & $(0.0010)$ & $(0.0022)$ & $(0.0029)$ & $(0.0026)$ \\
\hline \multirow[t]{2}{*}{ TARROA } & $0.228 * * *$ & $0.190 *$ & $0.302 *$ & 0.258 \\
\hline & $(0.0715)$ & $(0.1013)$ & $(0.1744)$ & $(0.1579)$ \\
\hline \multirow[t]{2}{*}{ TRANSVAL } & $-0.003 * * *$ & -0.002 & $-0.005^{* *}$ & $-0.008 * * *$ \\
\hline & $(0.0000)$ & $(0.0000)$ & $(0.0000)$ & $(0.0000)$ \\
\hline \multirow[t]{2}{*}{ REG } & 0.015 & 0.021 & $0.036 *$ & 0.025 \\
\hline & $(0.0089)$ & $(0.0146)$ & $(0.0200)$ & $(0.0173)$ \\
\hline \multirow[t]{2}{*}{ STATE } & -0.007 & -0.022 & -0.026 & -0.016 \\
\hline & $(0.0085)$ & $(0.0132)$ & $(0.0187)$ & $(0.0189)$ \\
\hline \multirow[t]{2}{*}{ HORIZONTAL } & 0.009 & -0.001 & 0.020 & 0.027 \\
\hline & $(0.0071)$ & $(0.0117)$ & $(0.0175)$ & $(0.0165)$ \\
\hline \multirow[t]{2}{*}{ Intercept } & -0.000 & 0.016 & 0.001 & 0.011 \\
\hline & $(0.0067)$ & $(0.0118)$ & $(0.0197)$ & $(0.0170)$ \\
\hline $\operatorname{adj} . R^{2}$ & 0.164 & 0.025 & 0.077 & 0.160 \\
\hline Obs & 60 & 60 & 60 & 60 \\
\hline
\end{tabular}




\section{Table 8: Political Connections and Merger Activity}

Panels $\mathrm{A}$ and $\mathrm{B}$ report results of the following regression:

$N_{i, t}=\beta_{0}+\beta_{1}$ POL $_{i, t}+\beta_{2}$ RELSIZE $_{i, t}+\beta_{3}$ ACQSIZE $_{i, t}+\beta_{4}$ ACQROA $_{i, t}+\beta_{5}$ ACQMB $_{i, t}+\beta_{6}$ ACQCASHTA $_{i, t}+$ $\beta_{7} A_{C Q L E V}+\beta_{8, t} A_{C Q E I N D E X}{ }_{i, t}+\beta_{9} I_{N D D I R}, t+\beta_{10} A C Q B S I Z E_{i, t}+\beta_{11} A C Q D U A L_{i, t}+\beta_{12}$ ACQINST $_{i, t}+$ $\beta_{13}$ ACQHERF $_{i, t}+\beta_{14}$ TARSIZE $_{i, t}+\beta_{15}$ TARROA $_{i, t}++\beta_{16}$ TARMB $_{i, t}+\beta_{17}$ TARCASHTA $_{i, t}+\beta_{18}$ TARLEV $_{i, t}+$ $\beta_{19}$ TARHERF $_{i, t}+\beta_{20}$ RUNUP $_{i, t}+\beta_{21}$ CASH $_{i, t}+\beta_{22}$ VERTICAL $_{i, t}+\beta_{23}$ EQINPAY $_{i, t}+\beta_{24}$ TENDOFFER $_{i, t}+$ $\beta_{25}$ COMPDEAL $_{i, t}++\beta_{26}$ HOSTDEAL $_{i, t}+$ Industry Dummies + YearDummies $+\varepsilon_{i, t}$, where $N$ is the natural logarithm of number of bids in Columns (1)-(3) and the natural logarithm of the number of acquisitions in Columns (4)-(6). POL is one of the three measures of connectedness: POL1 indicates whether the bidder has a former politician or industry regulator on its board or management team, $P O L 2$ defines politically connected firms as those firms which have a former politician, regulator on their board or management team, or former senior member of the military. POL3- defines politically connected firms as those firms which have a former politician, regulator, senior military officer, or lawyer on the board or management team. RELSIZE is acquirer market capitalization scaled by target market capitalization. Acquirer (target) characteristics include: ACQ(TAR)SIZE - market capitalization, $A C Q(T A R) R O A$ - return on assets estimated as is the ratio of operating earnings to firms' total assets, $A C Q(T A R) M B$ - market-to-book ratio estimated as the market value of equity divided by book value, ACQ(TAR)CSHTA - cash scaled by total assets, ACQ(TAR)LEV - total debt scaled by total assets, and $A C Q(T A R) H E R F$ - the Herfindahl index of industry concertation based on sales. Governance attributes of the acquirer include: ACQ E-INDEX, ACQ INDDIR, ACQBSIZE, ACQDUAL, and ACQINST, - entrenchment index from Bebchuk et al. (2009), proportion of independent directors, board size, CEO/Chairman duality, and institutional ownership, and the Herfindahl index of industry concertation based on sale, respectively. RUNUP is target share price runup from $t$-230 to $t$ - 11 days prior to the bid announcement. Deal characteristics include: $C A S H$, VERTICAL, EQINPAY, TENDOFFER, COMPDEAL, and HOSTILEDEAL - dummy variables that take value one if the transaction includes a cash component, if the acquisition is vertical according to Acemoglu et al. (2009), if the deal includes compensation to the target firm's shareholders in the form of the bidder firm's equity, if it is a tenderoffer, if there is more than one bidder, and if it is hostile according to SDC, respectively. Panel A is estimated for all deals and Panel B - for the non-diversifying deals. Panels $C$ and D compare the difference in the number of bids between the periods ( $t-3$ to $t-1)-(t+1$ to $t+3)$ and $(t+1$ to $t+5)-(t-5$ to $t-1)$, and (t to $t+3)-(t-3$ to $t-1)$ and $(t$ to $t+5)$ - (t-5 to t-1), respectively, where $t$ represents the year the connected individual joined the firm. $P C$ indicates politically connected firms, and NPC refers to non-connected firms. In Panels A and B White's heteroscedasticityrobust standard errors are shown in parentheses. *, **, and $* * *$ indicate significance at the $10 \%, 5 \%$, and $1 \%$ levels, respectively.

Panel A: All Bids and Acquisitions

\begin{tabular}{|c|c|c|c|c|c|c|}
\hline & (1) & $(2)$ & (3) & (4) & (5) & (6) \\
\hline & \multicolumn{3}{|c|}{ Number of Bids } & \multicolumn{3}{|c|}{ Number of Acquisitions } \\
\hline \multirow[t]{2}{*}{ POL1 } & 0.11 & & & 0.09 & & \\
\hline & $(0.0$ & & & $(0.0$ & & \\
\hline \multirow[t]{2}{*}{ POL2 } & & 0.08 & & & 0.08 & \\
\hline & & $(0.0$ & & & $(0.0$ & \\
\hline \multirow[t]{2}{*}{ POL3 } & & & 0.12 & & & $0.112 * * *$ \\
\hline & & & $(0.0$ & & & $(0.041)$ \\
\hline
\end{tabular}




\begin{tabular}{|c|c|c|c|c|c|c|}
\hline \multicolumn{7}{|c|}{ Acquirer Characteristics } \\
\hline \multirow[t]{2}{*}{ RELSIZE } & 0.043 & 0.041 & 0.028 & 0.020 & 0.019 & 0.010 \\
\hline & $(0.103)$ & $(0.104)$ & $(0.104)$ & $(0.114)$ & $(0.115)$ & $(0.115)$ \\
\hline \multirow[t]{2}{*}{ ACQSIZE } & $0.007 * * *$ & $0.007 * * *$ & $0.007 * * *$ & $0.007 * * *$ & $0.007 * * *$ & $0.007^{* * *}$ \\
\hline & $(0.001)$ & $(0.001)$ & $(0.001)$ & $(0.001)$ & $(0.001)$ & $(0.001)$ \\
\hline \multirow[t]{2}{*}{ ACQROA } & 0.345 & 0.335 & 0.320 & 0.414 & 0.408 & 0.386 \\
\hline & $(0.319)$ & $(0.320)$ & $(0.323)$ & $(0.344)$ & $(0.345)$ & $(0.350)$ \\
\hline \multirow[t]{2}{*}{ ACQMB } & -0.013 & -0.013 & -0.013 & -0.013 & -0.013 & -0.013 \\
\hline & $(0.008)$ & $(0.008)$ & $(0.008)$ & $(0.008)$ & $(0.008)$ & $(0.008)$ \\
\hline \multirow[t]{2}{*}{ ACQCASHTA } & -0.130 & -0.133 & -0.180 & -0.095 & -0.097 & -0.134 \\
\hline & $(0.252)$ & $(0.252)$ & $(0.253)$ & $(0.264)$ & $(0.264)$ & $(0.264)$ \\
\hline \multirow[t]{2}{*}{ ACQLEV } & 0.147 & 0.148 & 0.142 & 0.175 & 0.172 & 0.162 \\
\hline & $(0.178)$ & $(0.178)$ & $(0.178)$ & $(0.190)$ & $(0.190)$ & $(0.192)$ \\
\hline \multirow[t]{2}{*}{ ACQ E-INDEX } & $-0.031^{*}$ & $-0.032 *$ & $-0.034^{*}$ & -0.027 & -0.028 & $-0.030 *$ \\
\hline & $(0.018)$ & $(0.018)$ & $(0.018)$ & $(0.018)$ & $(0.018)$ & $(0.018)$ \\
\hline \multirow[t]{2}{*}{ ACQ INDDIR } & $-0.232 *$ & $-0.228^{*}$ & -0.206 & -0.145 & -0.143 & -0.128 \\
\hline & $(0.134)$ & $(0.135)$ & $(0.134)$ & $(0.137)$ & $(0.138)$ & $(0.138)$ \\
\hline \multirow[t]{2}{*}{ ACQBSIZE } & $0.043^{* * *}$ & $0.043^{* * *}$ & $0.041^{* * *}$ & $0.042^{* * *}$ & $0.042 * * *$ & $0.040^{* * *}$ \\
\hline & $(0.009)$ & $(0.009)$ & $(0.009)$ & $(0.009)$ & $(0.009)$ & $(0.009)$ \\
\hline \multirow[t]{2}{*}{ ACQDUAL } & 0.067 & 0.067 & 0.059 & 0.070 & 0.069 & 0.062 \\
\hline & $(0.047)$ & $(0.047)$ & $(0.047)$ & $(0.049)$ & $(0.049)$ & $(0.049)$ \\
\hline \multirow[t]{2}{*}{ ACQINST } & $-0.471 * *$ & $-0.476 * *$ & $-0.447 * *$ & $-0.410^{*}$ & $-0.416^{*}$ & $-0.391 *$ \\
\hline & $(0.199)$ & $(0.199)$ & $(0.198)$ & $(0.214)$ & $(0.214)$ & $(0.213)$ \\
\hline \multirow[t]{2}{*}{ ACQHERF } & -0.025 & -0.021 & -0.024 & 0.000 & 0.003 & 0.000 \\
\hline & $(0.085)$ & $(0.085)$ & $(0.085)$ & $(0.087)$ & $(0.087)$ & $(0.087)$ \\
\hline \multicolumn{7}{|c|}{$\underline{\text { Target Characteristics }}$} \\
\hline \multirow[t]{2}{*}{ TARSIZE } & -0.004 & -0.003 & -0.001 & -0.005 & -0.005 & -0.003 \\
\hline & $(0.020)$ & $(0.020)$ & $(0.020)$ & $(0.022)$ & $(0.022)$ & $(0.022)$ \\
\hline
\end{tabular}




\begin{tabular}{lllllll}
\hline TARROA & -0.079 & -0.068 & -0.081 & -0.110 & -0.101 & -0.113 \\
TARMB & $(0.139)$ & $(0.141)$ & $(0.140)$ & $(0.149)$ & $(0.149)$ & $(0.150)$ \\
& $0.015^{*}$ & 0.014 & 0.013 & $0.018^{*}$ & $0.018^{*}$ & $0.017^{*}$ \\
TARCASHTA & $(0.009)$ & $(0.009)$ & $(0.009)$ & $(0.009)$ & $(0.009)$ & $(0.009)$ \\
& 0.165 & 0.164 & 0.159 & 0.184 & 0.183 & 0.180 \\
TARLEV & $(0.160)$ & $(0.161)$ & $(0.159)$ & $(0.165)$ & $(0.166)$ & $(0.167)$ \\
& -0.006 & -0.005 & -0.011 & -0.090 & -0.090 & -0.097 \\
TARHERF & $(0.137)$ & $(0.138)$ & $(0.136)$ & $(0.144)$ & $(0.145)$ & $(0.144)$ \\
& 0.029 & 0.029 & 0.026 & 0.005 & 0.005 & 0.001 \\
RUNUP & $(0.048)$ & $(0.048)$ & $(0.048)$ & $(0.050)$ & $(0.049)$ & $(0.049)$ \\
& 0.108 & 0.113 & 0.118 & 0.088 & 0.090 & 0.093 \\
& $(0.090)$ & $(0.091)$ & $(0.090)$ & $(0.093)$ & $(0.094)$ & $(0.093)$
\end{tabular}

Deal Characteristics

\begin{tabular}{|c|c|c|c|c|c|c|}
\hline CASH & $\begin{array}{l}-0.097 * * \\
(0.048)\end{array}$ & $\begin{array}{l}-0.097 * * \\
(0.048)\end{array}$ & $\begin{array}{l}-0.093^{*} \\
(0.048)\end{array}$ & $\begin{array}{l}-0.102 * * \\
(0.050)\end{array}$ & $\begin{array}{l}-0.101 * * \\
(0.050)\end{array}$ & $\begin{array}{l}-0.096 * \\
(0.050)\end{array}$ \\
\hline \multirow[t]{2}{*}{ VERTICAL } & -0.064 & -0.066 & -0.071 & -0.063 & -0.064 & -0.069 \\
\hline & $(0.058)$ & $(0.058)$ & $(0.058)$ & $(0.060)$ & $(0.060)$ & $(0.060)$ \\
\hline \multirow[t]{2}{*}{ EQINPAY } & -0.033 & -0.035 & -0.033 & -0.013 & -0.014 & -0.010 \\
\hline & $(0.050)$ & $(0.050)$ & $(0.050)$ & $(0.054)$ & $(0.055)$ & $(0.054)$ \\
\hline \multirow[t]{2}{*}{ TENDOFFER } & -0.004 & -0.004 & -0.004 & 0.012 & 0.012 & 0.012 \\
\hline & $(0.046)$ & $(0.047)$ & $(0.047)$ & $(0.049)$ & (0.049) & $(0.049)$ \\
\hline \multirow[t]{2}{*}{ COMPDEAL } & -0.084 & -0.084 & -0.081 & $-0.205^{* *}$ & $-0.205 * *$ & $-0.201 * *$ \\
\hline & $(0.075)$ & $(0.075)$ & $(0.075)$ & $(0.093)$ & $(0.093)$ & $(0.093)$ \\
\hline \multirow[t]{2}{*}{ HOSTILEDEAL } & $0.174 *$ & $0.177^{*}$ & 0.183* & $0.238^{*}$ & $0.244^{*}$ & $0.246^{*}$ \\
\hline & $(0.095)$ & $(0.095)$ & $(0.096)$ & $(0.135)$ & $(0.137)$ & $(0.137)$ \\
\hline \multirow[t]{2}{*}{ Intercept } & $0.947 * * *$ & $0.975^{* * *}$ & $0.945^{* * *}$ & $0.847^{* *}$ & $0.867 * * *$ & $0.844^{* *}$ \\
\hline & $(0.318)$ & $(0.320)$ & $(0.317)$ & $(0.334)$ & $(0.335)$ & $(0.333)$ \\
\hline $\operatorname{adj} . \mathrm{R}^{2}$ & 0.489 & 0.486 & 0.490 & 0.503 & 0.502 & 0.505 \\
\hline
\end{tabular}




\begin{tabular}{lllllll}
\hline Obs & 870 & 870 & 870 & 792 & 792 & 792 \\
\hline
\end{tabular}

Panel B: Non-Diversifying Bids and Acquisitions

\begin{tabular}{|c|c|c|c|c|c|c|}
\hline & (1) & (2) & (3) & (4) & (5) & (6) \\
\hline & \multicolumn{3}{|c|}{ Non-Diversifying Bids } & \multicolumn{3}{|c|}{ Non-Diversifying Acquisitions } \\
\hline \multirow[t]{2}{*}{ POL1 } & $0.338^{*}$ & & & $0.379 * *$ & & \\
\hline & $(0.173)$ & & & $(0.183)$ & & \\
\hline \multirow[t]{2}{*}{ POL2 } & & $0.319 *$ & & & $0.360^{*}$ & \\
\hline & & $(0.174)$ & & & $(0.184)$ & \\
\hline \multirow[t]{2}{*}{ POL3 } & & & $0.314^{*}$ & & & $0.326^{*}$ \\
\hline & & & $(0.160)$ & & & (0.173) \\
\hline \multicolumn{7}{|c|}{ Acquirer Characteristics } \\
\hline \multirow[t]{2}{*}{ RELSIZE } & 0.362 & 0.366 & 0.311 & 0.386 & 0.397 & 0.335 \\
\hline & $(0.417)$ & $(0.418)$ & $(0.418)$ & $(0.450)$ & $(0.452)$ & $(0.454)$ \\
\hline \multirow[t]{2}{*}{ ACQSIZE } & $0.025^{* * *}$ & $0.025^{* * *}$ & $0.025^{* * *}$ & $0.024^{* * *}$ & $0.024^{* * *}$ & $0.025^{* * *}$ \\
\hline & $(0.005)$ & $(0.005)$ & $(0.005)$ & $(0.005)$ & $(0.005)$ & $(0.005)$ \\
\hline \multirow[t]{2}{*}{ ACQROA } & 1.619 & 1.617 & 1.531 & 1.431 & 1.428 & 1.314 \\
\hline & $(1.367)$ & $(1.367)$ & $(1.361)$ & $(1.432)$ & $(1.432)$ & $(1.436)$ \\
\hline \multirow[t]{2}{*}{ ACQMB } & $-0.070 *$ & $-0.071^{*}$ & $-0.071^{*}$ & -0.065 & -0.066 & -0.066 \\
\hline & $(0.039)$ & $(0.039)$ & $(0.039)$ & $(0.040)$ & $(0.040)$ & $(0.040)$ \\
\hline \multirow[t]{2}{*}{ ACQCASHTA } & $2.432 *$ & $2.410^{*}$ & $2.306^{*}$ & 1.849 & 1.835 & 1.743 \\
\hline & $(1.393)$ & $(1.391)$ & $(1.397)$ & $(1.387)$ & $(1.386)$ & $(1.388)$ \\
\hline \multirow[t]{2}{*}{ ACQLEV } & $1.775^{* *}$ & $1.786^{* *}$ & $1.755^{* *}$ & $1.797^{* *}$ & $1.796 * *$ & $1.741^{* *}$ \\
\hline & $(0.792)$ & $(0.794)$ & $(0.789)$ & $(0.876)$ & $(0.876)$ & $(0.876)$ \\
\hline \multirow[t]{2}{*}{ ACQ E-INDEX } & $-0.122 *$ & $-0.125^{*}$ & $-0.131^{*}$ & -0.115 & -0.118 & $-0.125^{*}$ \\
\hline & $(0.071)$ & $(0.071)$ & $(0.071)$ & $(0.076)$ & $(0.076)$ & $(0.076)$ \\
\hline \multirow[t]{2}{*}{ ACQ INDDIR } & -0.839 & -0.851 & -0.754 & -0.716 & -0.726 & -0.631 \\
\hline & $(0.545)$ & $(0.547)$ & (0.539) & (0.579) & $(0.581)$ & $(0.576)$ \\
\hline
\end{tabular}




\begin{tabular}{lllllllll}
\hline ACQBSIZE & $0.090^{* * *}$ & $0.090^{* * *}$ & $0.086^{* * *}$ & & $0.092^{* * *}$ & $0.092^{* * *}$ & $0.088^{* * *}$ \\
& $(0.029)$ & $(0.029)$ & $(0.030)$ & & $(0.030)$ & $(0.031)$ & $(0.031)$ \\
ACQDUAL & 0.199 & 0.199 & 0.176 & 0.132 & 0.132 & 0.107 \\
& $(0.202)$ & $(0.202)$ & $(0.203)$ & $(0.211)$ & $(0.211)$ & $(0.213)$ \\
ACQINST & $-1.955^{* *}$ & $-1.973^{* *}$ & $-1.891^{* *}$ & $-1.723^{*}$ & $-1.749^{*}$ & $-1.667 *$ \\
& $(0.877)$ & $(0.880)$ & $(0.874)$ & $(0.905)$ & $(0.907)$ & $(0.904)$ \\
ACQHERF & -0.007 & 0.005 & 0.000 & 0.088 & 0.100 & 0.093 \\
& $(0.382)$ & $(0.382)$ & $(0.383)$ & $(0.398)$ & $(0.398)$ & $(0.398)$
\end{tabular}

Target Characteristics

$\begin{array}{lllllll}\text { TARSIZE } & 0.012 & 0.012 & 0.020 & 0.014 & 0.013 & 0.023 \\ \text { TARROA } & (0.094) & (0.094) & (0.095) & (0.100) & (0.100) & (0.101) \\ & -0.908 & -0.867 & -0.912 & -0.944 & -0.906 & -0.946 \\ \text { TARMB } & (0.642) & (0.640) & (0.643) & (0.676) & (0.673) & (0.678) \\ & 0.041 & 0.040 & 0.036 & 0.044 & 0.044 & 0.039 \\ \text { TARCASHTA } & (0.040) & (0.040) & (0.040) & (0.044) & (0.044) & (0.045) \\ & 0.846 & 0.837 & 0.833 & 0.983 & 0.976 & 0.974 \\ \text { TARLEV } & (0.837) & (0.839) & (0.837) & (0.895) & (0.896) & (0.899) \\ & -0.477 & -0.474 & -0.492 & -0.528 & -0.528 & -0.549 \\ \text { TARHERF } & (0.556) & (0.560) & (0.558) & (0.618) & (0.622) & (0.624) \\ & -0.215 & -0.214 & -0.224 & -0.250 & -0.249 & -0.258 \\ \text { RUNUP } & (0.204) & (0.204) & (0.203) & (0.223) & (0.223) & (0.222) \\ & 0.748^{*} & 0.755^{*} & 0.780^{*} & 0.673 & 0.676 & 0.705 * \\ & (0.398) & (0.399) & (0.399) & (0.411) & (0.412) & (0.411)\end{array}$

Deal Characteristics

\begin{tabular}{|c|c|c|c|c|c|c|}
\hline CASH & -0.050 & -0.053 & -0.035 & -0.073 & $\begin{array}{l}-0.075 \\
03075\end{array}$ & $\begin{array}{l}-0.048 \\
(0210)\end{array}$ \\
\hline VERTICAL & $0.910 * * *$ & $0.904^{* * *}$ & $0.889 * * *$ & $0.846 * *$ & $0.840 * *$ & $0.824 * *$ \\
\hline
\end{tabular}




\begin{tabular}{llllllll}
\hline \multirow{2}{*}{ EQINPAY } & $(0.332)$ & $(0.332)$ & $(0.333)$ & & $(0.344)$ & $(0.344)$ & $(0.345)$ \\
TENDOFFER & -0.027 & -0.035 & -0.026 & & -0.064 & -0.072 & -0.053 \\
& $(0.202)$ & $(0.202)$ & $(0.201)$ & & $(0.215)$ & $(0.215)$ & $(0.213)$ \\
COMPDEAL & -0.191 & -0.192 & -0.193 & & -0.234 & -0.234 & -0.237 \\
& $(0.212)$ & $(0.212)$ & $(0.212)$ & & $(0.226)$ & $(0.226)$ & $(0.226)$ \\
HOSTILEDEAL & -0.195 & -0.193 & -0.187 & & $-0.685^{*}$ & $-0.682^{*}$ & $-0.675^{*}$ \\
& $(0.371)$ & $(0.371)$ & $(0.371)$ & & $(0.404)$ & $(0.403)$ & $(0.404)$ \\
Intercept & $1.470^{*}$ & $1.476^{*}$ & $1.500^{*}$ & & $2.167^{*}$ & $2.182^{*}$ & $2.210^{*}$ \\
& $(0.838)$ & $(0.837)$ & $(0.843)$ & & $(1.120)$ & $(1.116)$ & $(1.132)$ \\
adj. $\mathrm{R}^{2}$ & -0.173 & -0.098 & -0.159 & & -0.007 & 0.062 & 0.011 \\
Obs & $(1.305)$ & $(1.304)$ & $(1.303)$ & & $(1.393)$ & $(1.393)$ & $(1.392)$ \\
\hline
\end{tabular}

\begin{tabular}{|c|c|c|c|c|}
\hline \multicolumn{5}{|c|}{$\begin{array}{l}\text { Panel C: Diff-in-Diff Test of Political Hiring and Number of Bids } \\
\text { Event Window: }(t+1 \text { to } t+3)-(t-3 \text { to } t-1) \text { and }(t+1 \text { to } t+5)-(t-5 \text { to } t-1)\end{array}$} \\
\hline & PC & NPC & Difference & P-value \\
\hline Three Year Public Bids (t+1 to $t+3)-(t-3$ to $t-1)$ & 0.563 & 0.039 & $0.524 * * *$ & $(<.0001)$ \\
\hline Three Year All Bids $(t+1$ to $t+3)-(t-3$ to $t-1)$ & 0.516 & 0.008 & $0.508 * * *$ & $(0.003)$ \\
\hline Five Year Public Bids $(t+1$ to $t+5)-(t-5$ to $t-1)$ & 0.711 & 0.078 & $0.633 * * *$ & $(0.000)$ \\
\hline Five Year All Bids (t+1 to $t+5)-(t-5$ to $t-1)$ & 0.586 & 0.008 & $0.578^{* *}$ & $(0.01)$ \\
\hline
\end{tabular}

\begin{tabular}{|c|c|c|c|c|}
\hline \multicolumn{5}{|c|}{$\begin{array}{l}\text { Panel D: Diff-in-Diff Test of Political Hiring and Number of Bids } \\
\text { Event Window: }(t \text { to } t+3)-(t-3 \text { to } t-1) \text { and }(t \text { to } t+5)-(t-5 \text { to } t-1)\end{array}$} \\
\hline & PC & NPC & Difference & P-value \\
\hline Three Year Public Acquisitions ( $t$ to $t+3)-(t-3$ to $t-1)$ & 0.82 & 0.188 & $0.632 * * *$ & $(<.0001)$ \\
\hline Three Year All Acquisitions (t to $t+3)-(t-3$ to $t-1)$ & 0.883 & 0.266 & $0.617 * * *$ & $(0.001)$ \\
\hline Five Year Public Acquisitions ( $t$ t $t+5)-(t-5$ to $t-1)$ & 0.969 & 0.227 & $0.742 * * *$ & $(<.0001)$ \\
\hline Five Year All Acquisitions ( $t$ to $t+5)-(t-5$ to $t-1)$ & 0.953 & 0.266 & $0.687 * * *$ & $(0.003)$ \\
\hline
\end{tabular}




\section{Table 9: Merger Target Size and Acquirer Political Connections}

This table report results of the following regression: $T A R S I Z E_{i, t}=\beta_{0}+\beta_{1} P O L_{i, t}+\beta_{2} A C Q S I Z E_{i, t}+\beta_{3} A C Q R O A_{i, t}+\beta_{4} A C Q M B_{i, t}+\beta_{5} A C Q C A S H T A_{i, t}+$ $\beta_{6} A C Q L E V_{i, t}+$ Industry Dummies + YearDummies $+\varepsilon_{i, t}$, where TARSIZE is one of the three measures of target size: the natural logarithm of market capitalization, the natural logarithm of total assets, and the natural logarithm of total sales. POL1 indicates whether the bidder has a former politician or industry regulator on its board or management team, POL2 defines politically connected firms as those firms which have a former politician, regulator on their board or management team, or former senior member of the military. POL3 defines politically connected firms as those firms which have a former politician, regulator, senior military officer, or lawyer on the board or management team. Acquirer characteristics include: ACQSIZE - market capitalization, ACQROA - return on assets estimated as is the ratio of operating earnings to firms' total assets, $A C Q(T A R) M B$ - market-to-book ratio estimated as the market value of equity divided by book value, ACQCASHTA - cash scaled by total assets, and ACQLEV - total debt scaled by total assets. White's heteroscedasticity-robust standard errors are shown in parentheses. $*, * *$, and $* * *$ indicate significance at the $10 \%, 5 \%$, and $1 \%$ levels, respectively.

\begin{tabular}{|c|c|c|c|c|c|c|c|c|c|}
\hline & (1) & $(2)$ & (3) & (4) & (5) & (6) & (7) & (8) & (9) \\
\hline & \multicolumn{3}{|c|}{ Market Capitalization } & \multicolumn{3}{|c|}{ Total Assets } & \multicolumn{3}{|c|}{ Total Sales } \\
\hline \multirow[t]{2}{*}{ POL1 } & $0.196 *$ & & & $0.172 *$ & & & $0.151 *$ & & \\
\hline & $(0.1014)$ & & & (0.0948) & & & $(0.0868)$ & & \\
\hline \multirow[t]{2}{*}{ POL2 } & & $0.185^{*}$ & & & $0.166^{*}$ & & & 0.131 & \\
\hline & & $(0.0995)$ & & & $(0.0926)$ & & & $(0.0851)$ & \\
\hline \multirow[t]{2}{*}{ POL3 } & & & 0.123 & & & 0.101 & & & 0.082 \\
\hline & & & $(0.0929)$ & & & $(0.0838)$ & & & $(0.0770)$ \\
\hline \multirow[t]{2}{*}{ ACQSIZE } & $0.015 * * *$ & $0.015 * * *$ & $0.015 * * *$ & $0.013 * * *$ & $0.013 * * *$ & $0.013 * * *$ & $0.010 * * *$ & $0.010 * * *$ & $0.010 * * *$ \\
\hline & $(0.0021)$ & $(0.0021)$ & $(0.0021)$ & $(0.0021)$ & $(0.0021)$ & $(0.0021)$ & $(0.0018)$ & $(0.0018)$ & $(0.0018)$ \\
\hline \multirow[t]{2}{*}{ ACQROA } & 0.831 & 0.833 & 0.861 & 0.728 & 0.728 & 0.756 & $1.799 * * *$ & $1.803^{* * *}$ & $1.824 * * *$ \\
\hline & $(0.6228)$ & $(0.6228)$ & $(0.6236)$ & $(0.5216)$ & $(0.5216)$ & $(0.5225)$ & $(0.4789)$ & $(0.4787)$ & $(0.4782)$ \\
\hline \multirow[t]{2}{*}{ ACQMB } & $0.106 * * *$ & $0.106 * * *$ & $0.107 * * *$ & 0.019 & 0.019 & 0.019 & 0.006 & 0.006 & 0.007 \\
\hline & $(0.0195)$ & (0.0195) & (0.0195) & $(0.0168)$ & (0.0169) & (0.0169) & $(0.0155)$ & $(0.0155)$ & $(0.0155)$ \\
\hline
\end{tabular}




\begin{tabular}{|c|c|c|c|c|c|c|c|c|c|}
\hline \multirow[t]{2}{*}{ ACQCASHTA } & $-1.026 *$ & $-1.027^{*}$ & $-1.065^{*}$ & $-1.162^{* *}$ & $-1.163^{* *}$ & $-1.195^{* *}$ & $-1.047 * *$ & $-1.049 * *$ & $-1.074^{* *}$ \\
\hline & $(0.5667)$ & $(0.5668)$ & $(0.5679)$ & $(0.4940)$ & $(0.4939)$ & $(0.4950)$ & $(0.4758)$ & $(0.4758)$ & $(0.4753)$ \\
\hline \multirow[t]{2}{*}{ ACQLEV } & $0.740^{*}$ & $0.741^{*}$ & $0.735^{*}$ & $1.096^{* * *}$ & $1.098 * * *$ & $1.091^{* * *}$ & $1.399 * * *$ & $1.399 * * *$ & $1.394 * * *$ \\
\hline & $(0.3818)$ & $(0.3818)$ & $(0.3815)$ & (0.3239) & $(0.3240)$ & $(0.3244)$ & $(0.2982)$ & $(0.2982)$ & $(0.2975)$ \\
\hline \multirow[t]{2}{*}{ Intercept } & $4.643^{* * *}$ & $4.645^{* * *}$ & $4.647 * * *$ & $4.922 * * *$ & $4.922 * * *$ & $4.928 * * *$ & $4.410 * * *$ & $4.415^{* * *}$ & $4.419 * * *$ \\
\hline & $(0.1668)$ & $(0.1669)$ & $(0.1713)$ & $(0.1555)$ & $(0.1556)$ & $(0.1591)$ & $(0.1514)$ & $(0.1515)$ & $(0.1544)$ \\
\hline adj. $\mathrm{R}^{2}$ & 0.239 & 0.239 & 0.238 & 0.380 & 0.380 & 0.379 & 0.374 & 0.374 & 0.373 \\
\hline Obs & 1478 & 1478 & 1478 & 1478 & 1478 & 1478 & 1478 & 1478 & 1478 \\
\hline
\end{tabular}




\section{Table 10: Post-Merger Performance of Acquiring Firm}

Panel A of this table reports the results of univariate analysis of the post-merger financial performance using BHAR. Firms which are politically connected according to POL1 have at least one member of the board of directors or a manager who is a former politician and regulator. POL2 defines politically connected firms as those firms which have a former politician, regulator on their board or management team, or former senior member of the military. POL3 defines politically connected firms as those firms which have a former politician, regulator, senior military officer, or lawyer on the board or management team. $P C$ indicates politically connected firms, and $N P C$ refers to non-connected firms. Panel B reports the results of the following multivariate regression: $B H A R=\beta_{0}+$ $\beta_{1}$ POL1 $_{i, t}+\beta_{2}$ ACQSIZE $_{i, t}+\beta_{3}$ ACQMBADJ $_{i, t}+\beta_{4}$ ACQLEV $_{i, t}+\beta_{5}$ ACQEINDEX $_{i, t}+\beta_{6}$ ACQBSIZE $_{i, t}+\beta_{7} A C Q D U A L_{i, t}+\beta_{8} A C Q I N S T_{i, t}+\beta_{9} C E O A G E_{i, t}+$ $\beta_{10}$ MISCEOAGE $_{i, t}+\beta_{11}$ TARROAADJ $_{i, t}+\beta_{12}$ RUNUP $_{i, t}+\beta_{13}$ TRANSVAL $_{i, t}+\beta_{14}$ CASH $_{i, t}+\beta_{14}$ WAVE $_{i, t}+\beta_{16}$ VERTICAL $_{i, t}+\beta_{17}$ TENDOFFER $_{i, t}+$ $\beta_{18}$ COMPDEAL $L_{i, t}+\beta_{19}$ HOSTDEAL $L_{i, t}+\beta_{19} S T A T E_{i, t}+$ Industry Dummies + YearDummies $+\varepsilon_{i, t}$, where BHAR is the buy-and-hold abnormal return estimated in Columns (1)-(5) for 1-5 years following the merger, respectively. Acquirer characteristics include: ACQSIZE - market capitalization, ACQMBADJ - the average market/book ratio of the acquirer's primary industry over the last three years, and ACQLEV - total debt scaled by total assets. ACQ E-INDEX, ACQBSIZE, and $A C Q D U A L$ are the entrenchment index from Bebchuk et al. (2009), board size, and CEO/Chairman duality, respectively. CEOAGE is CEO age, MCOEAGE is an indicator variable for missing information on CEO age. TARROAADJ - is the industry adjusted ROA for the target in the year prior to the bid announcement. RUNUP is target share price runup from $t-230$ to $t-11$ days prior to the bid announcement. Deal characteristics include: TRANSVAL, CASH, WAVE, VERTICAL, TENDOFFER, COMPDEAL, HOSTILEDEAL, and STATE - the natural logarithm of the transaction value, dummy variables that take value one if the transaction includes a cash component, if the date announced occurs during a merger wave following Harford (2005), if the acquisition is vertical according to Acemoglu et al. (2009), if it is a tender-offer, if there is more than one bidder, if it is hostile according to SDC, and if the target and acquirer are headquartered in the same state, respectively. White’s heteroscedasticity-robust standard errors are shown in parentheses. *, **, and *** indicate significance at the $10 \%$, $5 \%$, and $1 \%$ levels, respectively.

\section{Panel A: Univariate Statistics}

\begin{tabular}{|c|c|c|c|c|c|c|c|c|c|c|c|c|}
\hline & \multicolumn{4}{|c|}{ POL1 } & \multicolumn{4}{|c|}{ POL2 } & \multicolumn{4}{|c|}{ POL3 } \\
\hline & $\mathrm{PC}$ & NPC & Difference & P-Value & $\mathrm{PC}$ & NPC & Difference & P-Value & $\mathrm{PC}$ & NPC & Difference & P-Value \\
\hline BHAR1Y & $4.63 \%$ & $0.51 \%$ & $4.12 \%$ & $(0.176)$ & $4.05 \%$ & $0.76 \%$ & $3.29 \%$ & $(0.207)$ & $1.98 \%$ & $1.72 \%$ & $0.27 \%$ & $(0.475)$ \\
\hline BHAR2Y & $9.98 \%$ & $1.26 \%$ & $8.72 \%$ & $(0.136)$ & $9.30 \%$ & $1.53 \%$ & $7.77 \%$ & $(0.161)$ & $5.52 \%$ & $2.74 \%$ & $2.79 \%$ & $(0.335)$ \\
\hline BHAR3Y & $4.82 \%$ & $4.43 \%$ & $0.39 \%$ & $(0.479)$ & $3.98 \%$ & $4.87 \%$ & $-0.89 \%$ & $(0.451)$ & $5.98 \%$ & $3.07 \%$ & $2.91 \%$ & $(0.344)$ \\
\hline BHAR4Y & $17.17 \%$ & $9.53 \%$ & $7.64 \%$ & $(0.194)$ & $16.72 \%$ & $9.72 \%$ & $6.99 \%$ & $(0.214)$ & $16.11 \%$ & $7.82 \%$ & $8.28 \%$ & $(0.167)$ \\
\hline BHAR5Y & $24.86 \%$ & $6.30 \%$ & $18.55 \% * *$ & $(0.032)$ & $24.13 \%$ & $6.56 \%$ & $17.57 \% * *$ & $(0.040)$ & $17.18 \%$ & $7.57 \%$ & $9.61 \%$ & $(0.156)$ \\
\hline
\end{tabular}




\begin{tabular}{|c|c|c|c|c|c|}
\hline \multicolumn{6}{|c|}{ Panel B: Multivariate Analysis of Non-diversifying Acquisitions } \\
\hline \multirow{3}{*}{ POL1 } & $(1)$ & $(2)$ & (3) & (4) & (5) \\
\hline & $0.225 * *$ & $0.301 * *$ & $0.246 * *$ & $0.456 * * *$ & $0.535 * * *$ \\
\hline & $(0.1046)$ & $(0.1397)$ & $(0.1201)$ & $(0.1508)$ & $(0.1961)$ \\
\hline \multirow[t]{2}{*}{ ACQSIZE } & -0.002 & $-0.004^{* *}$ & $-0.005^{* *}$ & $-0.005^{* *}$ & -0.004 \\
\hline & $(0.0018)$ & $(0.0020)$ & $(0.0020)$ & $(0.0022)$ & $(0.0029)$ \\
\hline \multirow[t]{2}{*}{ ACQMBADJ } & 0.126 & 0.294 & -0.019 & -0.013 & -0.029 \\
\hline & $(0.1339)$ & $(0.1920)$ & $(0.1517)$ & $(0.1840)$ & $(0.2367)$ \\
\hline \multirow[t]{2}{*}{ ACQLEV } & -0.395 & -0.387 & -0.511 & -0.197 & -0.083 \\
\hline & $(0.3706)$ & $(0.4417)$ & (0.5195) & $(0.5252)$ & $(0.6717)$ \\
\hline \multirow[t]{2}{*}{ ACQ E-INDEX } & -0.020 & -0.063 & -0.045 & -0.091 & $-0.135^{*}$ \\
\hline & $(0.0475)$ & $(0.0594)$ & $(0.0529)$ & $(0.0598)$ & $(0.0812)$ \\
\hline \multirow[t]{2}{*}{ ACQBSIZE } & -0.197 & -0.073 & -0.137 & -0.294 & -0.374 \\
\hline & $(0.2448)$ & $(0.2940)$ & $(0.2976)$ & $(0.3401)$ & $(0.3977)$ \\
\hline \multirow[t]{2}{*}{ ACQDUAL } & -0.080 & -0.123 & 0.028 & 0.260 & $0.370 *$ \\
\hline & $(0.1664)$ & $(0.1866)$ & $(0.1607)$ & $(0.1790)$ & $(0.2159)$ \\
\hline \multirow[t]{2}{*}{ ACQINST } & -0.459 & -1.017 & $-1.747^{* *}$ & -0.699 & -0.376 \\
\hline & $(0.5060)$ & $(0.6192)$ & $(0.8539)$ & $(1.0744)$ & $(1.1057)$ \\
\hline \multirow[t]{2}{*}{ CEOAGE } & 0.009 & 0.010 & 0.008 & 0.003 & -0.004 \\
\hline & $(0.0068)$ & $(0.0096)$ & $(0.0086)$ & $(0.0097)$ & $(0.0141)$ \\
\hline \multirow[t]{2}{*}{ MISCEOAGE } & 0.453 & 0.562 & -0.045 & 0.000 & 0.000 \\
\hline & $(0.3921)$ & $(0.6090)$ & $(0.5888)$ & $(0.000)$ & $(0.000)$ \\
\hline \multirow[t]{2}{*}{ TAROAADJ } & 0.002 & -0.281 & -0.358 & -0.218 & -0.397 \\
\hline & $(0.2738)$ & $(0.3906)$ & $(0.3640)$ & $(0.4370)$ & $(0.4705)$ \\
\hline \multirow[t]{2}{*}{ RUNUP } & 0.037 & -0.275 & -0.372 & -0.545 & -0.496 \\
\hline & $(0.2946)$ & $(0.2741)$ & $(0.2970)$ & $(0.3345)$ & $(0.3702)$ \\
\hline \multirow[t]{2}{*}{ TRANSVAL } & -0.025 & -0.009 & -0.013 & -0.038 & -0.020 \\
\hline & $(0.0359)$ & $(0.0492)$ & $(0.0396)$ & $(0.0524)$ & $(0.0664)$ \\
\hline CASH & -0.092 & 0.006 & 0.165 & $0.292 * *$ & $0.370 * *$ \\
\hline
\end{tabular}




\begin{tabular}{|c|c|c|c|c|c|}
\hline & $(0.0982)$ & $(0.1229)$ & $(0.1206)$ & $(0.1361)$ & (0.1859) \\
\hline \multirow[t]{2}{*}{ WAVE } & -0.093 & -0.238 & 0.019 & -0.162 & -0.205 \\
\hline & $(0.1246)$ & $(0.1846)$ & $(0.1540)$ & $(0.1660)$ & $(0.1953)$ \\
\hline \multirow[t]{2}{*}{ VERTICAL } & 0.085 & 0.215 & 0.036 & 0.025 & 0.067 \\
\hline & $(0.0997)$ & $(0.1663)$ & $(0.1272)$ & $(0.1514)$ & $(0.1625)$ \\
\hline \multirow[t]{2}{*}{ TENDOFFER } & 0.056 & 0.125 & 0.057 & 0.130 & 0.164 \\
\hline & $(0.1006)$ & $(0.1431)$ & $(0.1678)$ & $(0.1900)$ & $(0.2293)$ \\
\hline \multirow[t]{2}{*}{ COMPDEAL } & -0.001 & 0.135 & 0.050 & -0.010 & -0.230 \\
\hline & $(0.1538)$ & $(0.2047)$ & $(0.1814)$ & $(0.1990)$ & $(0.2292)$ \\
\hline \multirow[t]{2}{*}{ HOSTILEDEAL } & -0.372 & -0.449 & -0.166 & -0.298 & -0.309 \\
\hline & $(0.2958)$ & $(0.3487)$ & $(0.4225)$ & $(0.5211)$ & $(0.6948)$ \\
\hline \multirow[t]{2}{*}{ STATE } & $0.296^{*}$ & 0.170 & 0.177 & $0.275^{*}$ & 0.205 \\
\hline & $(0.1596)$ & $(0.1499)$ & $(0.1493)$ & $(0.1526)$ & $(0.1800)$ \\
\hline \multirow[t]{2}{*}{ Intercept } & -0.458 & -0.875 & -0.316 & 0.838 & 0.954 \\
\hline & $(0.8300)$ & (1.1649) & (1.0419) & $(1.2775)$ & (1.5724) \\
\hline $\mathrm{R}^{2}$ & 0.282 & 0.337 & 0.425 & 0.489 & 0.488 \\
\hline Obs & 279 & 275 & 263 & 247 & 236 \\
\hline
\end{tabular}




\section{Table 11: Post-Merger Accounting Performance}

Panel A of this table reports the results of univariate analysis of the post-merger accounting IAROA following the procedure Wang and Xie (2009). Firms which are politically connected according to POL1 have at least one member of the board of directors or a manager who is a former politician and regulator. POL2 defines politically connected firms as those firms which have a former politician, regulator on their board or management team, or former senior member of the military. POL3 defines politically connected firms as those firms which have a former politician, regulator, senior military officer, or lawyer on the board or management team. $P C$ indicates politically connected firms, and $N P C$ refers to non-connected firms. Panel B reports the results of the following multivariate regression: IAROA $=\beta_{0}+\beta_{1}$ POL $_{i, t}+\beta_{2}$ TRANSVAL $_{i, t}+\beta_{3}$ ACQMB $_{i, t}+\beta_{4}$ ACQLEV $_{i, t}+\beta_{5}$ ACQEINDEX $_{i, t}+\beta_{6}$ TARSALE $_{i, t}+\beta_{7}$ TARLEV $_{i, t}+\beta_{8} V_{E R T I C A L_{i, t}}+$ $\beta_{9}$ TENDOFFER $_{i, t}+\beta_{10}$ COMPDEAL $_{i, t}+\beta_{11}$ HOSTDEAL $_{i, t}+$ Industry Dummies + YearDummies $+\varepsilon_{i, t}$, where IAROA is industry adjusted return on assets following the procedure Wang and Xie (2009). In Columns (1)-(5) IAROA is estimated up to 5 years from the merger, respectively. TRANSVAL is the natural logarithm of the transaction value include, $A C Q M B$ is the market-to-book ratio estimated as the market value of equity divided by book value, $A C Q(T A R) L E V$ is total debt scaled by total assets, ACQ E-INDEX is the entrenchment index from Bebchuk et al. (2009), and TARSALE is the natural logarithm of target sales. Deal characteristics include: VERTICAL, TENDOFFER, COMPDEAL, and HOSTILEDEAL - dummy variables that take value one if the acquisition is vertical according to Acemoglu et al. (2009), if it is a tender-offer, if there is more than one bidder, and if it is hostile according to SDC, respectively. White's heteroscedasticity-robust standard errors are shown in parentheses. *, **, and *** indicate significance at the $10 \%$, 5\%, and $1 \%$ levels, respectively.

\section{Panel A: Univariate Analysis}

\begin{tabular}{|c|c|c|c|c|c|c|c|c|c|c|c|c|}
\hline & \multicolumn{4}{|c|}{ POL1 } & \multicolumn{4}{|c|}{ POL2 } & \multicolumn{4}{|c|}{ POL3 } \\
\hline & $\mathrm{PC}$ & NPC & Difference & P-value & $\mathrm{PC}$ & NPC & Difference & P-value & $\mathrm{PC}$ & NPC & Difference & P-value \\
\hline IARIA1Y & $2.46 \%$ & $-0.51 \%$ & $2.97 \%$ & $(0.007)^{* * *}$ & $2.56 \%$ & $-0.62 \%$ & $3.18 \% * * *$ & $(0.004)$ & $1.03 \%$ & $-0.16 \%$ & $1.19 \%$ & $(0.143)$ \\
\hline IARIA2Y & $3.25 \%$ & $1.03 \%$ & $2.22 \%$ & $(0.054)^{*}$ & $3.34 \%$ & $0.94 \%$ & $2.40 \% * *$ & $(0.040)$ & $2.84 \%$ & $0.62 \%$ & $2.22 \% *$ & $(0.052)$ \\
\hline IARIA3Y & $4.45 \%$ & $0.74 \%$ & $3.71 \%$ & $(0.013)^{* *}$ & $4.17 \%$ & $0.83 \%$ & $3.34 \% * *$ & $(0.022)$ & $3.76 \%$ & $0.04 \%$ & $3.73 \% * *$ & (0.009) \\
\hline IARIA4Y & $3.40 \%$ & $0.35 \%$ & $3.05 \%$ & $(0.039)^{* *}$ & $2.99 \%$ & $0.52 \%$ & $2.48 \% *$ & $(0.085)$ & $2.33 \%$ & $0.33 \%$ & $2.00 \%$ & (0.109) \\
\hline IARIA5Y & $3.68 \%$ & $1.27 \%$ & $2.42 \%$ & $(0.178)$ & $3.30 \%$ & $1.45 \%$ & $1.85 \%$ & $(0.204)$ & $1.51 \%$ & $2.84 \%$ & $-1.33 \%$ & $(0.304)$ \\
\hline
\end{tabular}




\begin{tabular}{|c|c|c|c|c|c|}
\hline \multicolumn{6}{|c|}{ Panel B: Multivariate Analysis } \\
\hline & (1) & (2) & (3) & (4) & (5) \\
\hline \multirow[t]{2}{*}{ POL1 } & $0.020^{* *}$ & $0.028 *$ & 0.027 & $0.048^{*}$ & 0.023 \\
\hline & $(0.0096)$ & $(0.0160)$ & $(0.0233)$ & $(0.0285)$ & $(0.0379)$ \\
\hline \multirow[t]{2}{*}{ TRANSVAL } & -0.005 & -0.003 & -0.009 & -0.004 & -0.009 \\
\hline & $(0.0049)$ & $(0.0086)$ & $(0.0154)$ & $(0.0162)$ & $(0.0144)$ \\
\hline \multirow[t]{2}{*}{ ACQMB } & $0.006^{* * *}$ & $0.008^{* *}$ & $0.013^{* *}$ & 0.001 & 0.004 \\
\hline & $(0.0018)$ & $(0.0036)$ & $(0.0057)$ & $(0.0071)$ & $(0.0075)$ \\
\hline \multirow[t]{2}{*}{ ACQLEV } & 0.00001 & -0.00001 & -0.00003 & -0.00003 & -0.0005 \\
\hline & $(0.00002)$ & $(0.00003)$ & $(0.00015)$ & $(0.0001)$ & $(0.0001)$ \\
\hline \multirow[t]{2}{*}{ ACQ E-INDEX } & -0.004 & -0.009 & 0.006 & -0.003 & -0.011 \\
\hline & $(0.0039)$ & $(0.0073)$ & $(0.0079)$ & $(0.0104)$ & $(0.0139)$ \\
\hline \multirow[t]{2}{*}{ TARSALE } & -0.008 & -0.014 & -0.003 & 0.001 & 0.003 \\
\hline & $(0.0052)$ & $(0.0097)$ & $(0.0168)$ & $(0.0164)$ & $(0.0178)$ \\
\hline \multirow[t]{2}{*}{ TARLEV } & 0.000 & 0.001 & 0.001 & -0.000 & -0.000 \\
\hline & $(0.0002)$ & $(0.0003)$ & (0.0006) & $(0.0004)$ & $(0.0006)$ \\
\hline \multirow[t]{2}{*}{ VERTICAL } & $-0.025 * *$ & -0.015 & -0.011 & -0.019 & 0.038 \\
\hline & $(0.0124)$ & $(0.0248)$ & $(0.0318)$ & $(0.0403)$ & $(0.0471)$ \\
\hline \multirow[t]{2}{*}{ TENDOFFER } & -0.017 & 0.019 & 0.013 & 0.034 & 0.023 \\
\hline & $(0.0124)$ & $(0.0231)$ & $(0.0346)$ & $(0.0514)$ & $(0.0605)$ \\
\hline COMPDEAL & 0.020 & 0.040 & $0.065^{* *}$ & 0.018 & -0.018 \\
\hline
\end{tabular}




\begin{tabular}{llllll}
\hline \multirow{2}{*}{ HOSTILEDEAL } & $(0.0159)$ & $(0.0380)$ & $(0.0319)$ & $(0.0463)$ & $(0.0595)$ \\
& $-0.101^{* * *}$ & -0.092 & $-0.162^{* * *}$ & $-0.147^{*}$ & $-0.223^{* *}$ \\
Intercept & $(0.0333)$ & $(0.0582)$ & $(0.0602)$ & $(0.0808)$ & $(0.0989)$ \\
& $0.070^{* *}$ & 0.070 & 0.047 & 0.059 & -0.019 \\
\cline { 2 - 5 } $\mathrm{R}^{2}$ & $(0.0281)$ & $(0.0508)$ & $(0.0578)$ & $(0.0781)$ & $(0.1274)$ \\
Obs & 0.390 & 0.450 & 0.356 & 0.389 & 0.436 \\
\hline
\end{tabular}

